Smales, L. and Apergis, N. 2016. The influence of FOMC member characteristics on the monetary policy decision-making process. Journal of Banking and Finance. 64: pp. 216-231. 


\section{The influence of FOMC member characteristics on the monetary policy decision-making process}

\section{Abstract}

This paper provides new empirical evidence on a monetary policy committee with heterogeneous members whose decisions affect the efficacy of monetary policy. It thereby provides a link between the literature on monetary policy committees and central bank monetary policy implementation through monetary rules. Using a novel dataset of the idiosyncratic characteristics of FOMC members, over the period from August 1979 to February 2014, the empirical findings show that characteristics such as education, age, and, to a lesser extent, work experience are not important in understanding the FOMC decision-making process. Instead, the results point to the importance of time spent within the Federal Reserve System, tenure on the FOMC itself, and the influence of the Chair in shaping the decision-making process. The results are expected to have implications for the capacity of economic agents, as well as various markets in the economy, to more readily interpret public (monetary policy) information that reaches them. This makes the monetary policy decision process less noisy and, thus, enhances those agents' and markets' capability to attach the correct weight to this information.

Keywords: Monetary policy committees; characteristics of committee members; monetary policy rules: FOMC

\section{Introduction}

A great number of theoretical models emphasize the importance of private expectations in determining macroeconomic outcomes (King et al., 2008; Eusepi, 2010; Lamla and Maag, 2012; Givens, 2012; among others). Managing inflation and/or output expectations is a crucial feature of monetary policymaking, so the need for forward policy guidance is dramatically amplified, especially in crises periods and/or the downward trend of the business cycle.

In its traditional form, the expectations channel is subtle and fragile as it depends on the private agents' interpretation of interest rate changes. King (2005) states that “... because inflation expectations matter to the behaviour of the households and firms, the critical aspect of monetary policy is how decisions of the central bank affect those expectations ...”. Policy decisions can be understood in various ways and facilitating private agents' information processing is one reason why central banks complement their actions with communication to the public. Moreover, given 
the delay between policy actions and their real effects, central bank communication provides policymakers with a way to promptly affect private expectations to shorten the transmission lags of monetary policy.

The Federal Open Market Committee (FOMC) is responsible for the implementation of U.S. monetary policy, and the way monetary policy is implemented is extremely important in determining the course of output growth and inflation stability. Moreover, the effectiveness of monetary policy is sensitive to the link between monetary policy and asset price movements. This link has been of perennial interest to both policy makers and academic researchers, since such asset prices may affect real activity through the main channels of the transmission mechanism from asset prices to economic activity identified in the literature: households' wealth effects on consumption expenditure, Tobin's Q effects on investments, and financial accelerator effects on investments. However, Gilchrist and Leahy (2002) argue that the gains of including asset prices in monetary policy rules in practice adds little to stabilizing output and inflation. Moreover, financial markets can benefit from FOMC monetary policy decisions through an informational mechanism that conveys expectations about the future course of interest rates. This mechanism allows market participants to revise their expectations about the impact of those interest rates on future asset prices, and, through the monetary transmission channels, to the real economy (Rosa, 2013).

There has been acceptance in the literature that, although left in the shadows, governance structures have large consequences on macroeconomic performances (Al-Marhubi, 2004). Fry et al. (2000) report that only a minority of central banks make decisions by consensus, with the more popular method being a formal vote with decision by simple majority. Riboni and RugeMurcia (2013) document the role of dissents in monetary policy committees in the cases of the Bank of England and the Riksbank in increasing the forecasting performance of future monetary policy decisions. In a recent paper, Chappell et al. (2014) argue that monetary policy decisions turn out to be more effective if taken through a committees mechanism that on an individual basis, unless the committee members cede power to the chairman of that committee. Through an empirical model, they provide evidence in the cases of the Bank of England and in Sweden's 
Riksbank that the chairman in the former case cannot affect monetary policy decisions reached by committee members' votes, while in the latter case his impact is highly influential ${ }^{1}$.

The goal of our paper is to investigate in what way the idiosyncratic characteristics of FOMC members have influenced U.S. monetary policy decision-making over the period 19792014; a sample period covering the tenures of Paul Volcker, Alan Greenspan, and Ben Bernanke as Chair of the FOMC. This paper is, to our knowledge, the first to deal with the explicit influence of an extended number of biographical factors on the monetary policy decision-making process of the FOMC in the modern era. Using a novel, hand-collected, data-set we investigate the influence of characteristics of the composition of the FOMC in making monetary policy decisions, the performance of those decisions in terms of deviations from a benchmark rate, and dissent from the majority decision. This paper is the first to study the link between such diverse aspects of the FOMC decision-making process, and also the first to consider FOMC decisions in the modern era. This time-frame is of particular importance in light of the changing dynamics of the U.S. economy which has evolved through states of high inflation, low growth at the start of the Volcker era, to a 'goldilocks' period of low inflation, high growth in the Greenspan era, and onto the Great Recession and unconventional monetary policy of the Bernanke era; previous work has largely focused on earlier periods.

The results are expected to be of high importance to a variety of economic agents. To identify what really drives FOMC monetary policy decisions statements is not always completely anticipated. Hence, a greater understanding of such determinants may allow economic agents to revise their expectations more efficiently and rebalance their portfolios appropriately. In addition, economic agents can make use of the idiosyncratic information related to the characteristics of FOMC members to anticipate the future nature of monetary policy (vis-à-vis relative policy tightness) which has implications for long-term output and inflation performance.

\footnotetext{
${ }^{1}$ Chappell et al. (2014) qualify this conclusion since two changes in chairmanship of the Riksbank policy committee closely align with inflection points in the path of interest rates. This may lead to an inference that the new Chair has a large influence on policy, when in fact the association is coincidental. While this is a potential issue for our paper too, since the appointment of Bernanke to the Chair of the FOMC occurs not long before the start of the Great Recession, empirical testing seems to provide evidence that our results are robust.
} 
A better understanding of idiosyncratic drivers provides important benefits. For instance, improved forecasting of interest rates and asset prices would lead to a reduction in the volatility of asset prices, which in turn may make monetary policy more effective.

To foreshadow our empirical findings and utilising an ordered logit specification, we find there is an increase in the likelihood of Fed Funds target rate reductions as the Chair's tenure increases, and the proportion of FOMC members with experience in Government becomes greater. The importance of Chair tenure is re-emphasised when considering policy deviations from the Taylor Rule benchmark; deviations become greater, and generally more negative, as tenure increases. Conversely, as FOMC members spend more time working within the Federal Reserve System they seemingly develop a preference for monetary policy that is tighter than that suggested by the Taylor Rule. While dissent from the majority vote declines as the Chair is in situ for longer, FOMC members with a long history in the Fed and/or with a background in academia are most likely to express dissent at FOMC meetings. Finally, results for macroeconomic variables suggest that the FOMC acts to stabilise economic activity.

The remaining of the paper is organized as follows: Section 2 discusses related literature. Section 3 outlines the data used in our study. Section 4 details the empirical methodology and discusses the results of our empirical investigation. Section 5 summarises robustness testing, with a particular emphasis on period sub-samples, and section 6 concludes.

\section{Literature on monetary policy and monetary committees}

\section{Monetary Policy Decision-Making}

This paper links two major strands of the monetary policy literature: The first thread of literature looks at how monetary policy committees operate. Much of this literature uses a theoretical approach (Matsen and Roisland, 2005; Sibert, 2005), but there is a developing empirical literature with much of the evidence focusing on the Federal Open Market Committee (FOMC) of the Federal Reserve (Havrilesky, 1993; Blinder, 2004; Chappell et al., 2004). Notably, both research threads suggest that the personal characteristics of committee members may influence the monetary policy decision-making process.

Chappell et al. (1995) note that Presidents of regional Federal Reserve Banks are more likely to vote for tighter monetary policy, and members of the Board of Governors for looser 
monetary policy, something which is attributed to the average career experience (in private industry) and educational background (generally without $\mathrm{PhD}$ ) of Fed Bank Presidents. Caporale and Grier (2000) point to changes in the political party holding the presidency and a majority in Congress as the primary sources of changes in real interest rate regimes (given that both inflation and nominal interest rate components are heavily determined by monetary policy decisions). Chappell et al. (2004) address the important question of the competing pressures of majority rule, consensus building, and the power of the Chairman in decision-making. They construct an original data set recording desired Federal Funds rates for each member of the Fed Committee over the period 1970-78, with their results suggesting a disproportionate influence of the Chairman on the policy process.

Blinder (2004) discusses the 'quiet revolution' in central banking practice and provides evidence in favour of making monetary policy decisions by committee. Blinder (2007) extends this discussion to determination of the optimal method for central banks to make decisions in terms of individualistically (through voting) or collegially (through discussion), and how the decision is communicated to the markets, so as to maximize the expected monetary policy outcome. The article concludes that decision-making by committee has many advantages, but an individualistic committee may confuse observers by speaking with too many voices. As such, the appropriate central bank communication policy depends entirely on the idiosyncratic characteristics of decision makers.

The above results are confirmed by the empirical results of Riboni and Ruge-Murcia (2010) who investigate the implications of monetary policy making by committee under a number of different voting protocols. Specifically, they show that committees share unwritten rules and informal procedures that deliver observationally equivalent policy decisions vis-à-vis other schemes of monetary policy decision making.

Göhlmann and Vaubel (2007) present a multi-country analysis on how the education and occupational characteristics of central bankers affect their inflation preferences. Based on the importance of monetary policy efficacy to fight both inflation and large output gaps, their empirical findings highlight that, given the exchange rate regime and degree of central bank independence, central banks are shown to be more efficient in lowering inflation when the voting majority is held by former members of the central bank staff and economists as opposed to alternate occupational groups have. They attribute these findings to the fact that central banks 
primarily attract economists who are monetary conservatives, and the longer they remain with the central bank the more they are inclined towards price level stability owing to institutional tendencies.

Extending his prior work, Blinder (2009) discusses the specific features of monetary policy committees that may be used to design a monetary policy apparatus along the lines of best practice as determined in the literature. Salient features include the size and composition of the committee, the degree of consensus required, the role of the committee chair, voting procedures, methods of appointment and communication techniques.

Meade and Stasavage (2008) approach the role of idiosyncratic characteristics of committee members in monetary policy efficacy through a theoretical model. They investigate why increased levels of transparency, in the form of published verbatim transcripts of committee meetings, are not desirable if the quality of committee deliberation suffers as a result. The empirical test of their model provides robust evidence that Fed Governors and voting regional Federal Reserve Presidents have been less likely to express verbal dissent on policy decisions since the change in FOMC communication policy in 1993. Such results are expected to have significant implications for the design of monetary policy communication as well as for the operation of committee-based government decision making. Within a similar framework, Harris et al. (2011) investigate whether both the channels through which members of the Bank of England's Monetary Policy Committee are appointed can affect the decision to dissent from the majority decision and, also, whether differences in career backgrounds has an impact on the manner in which monetary policy tackles inflation and unemployment. Their empirical results suggest that, contrary to the FOMC literature, it is institutional constraints associated with UK monetary policy rather than the career background and other characteristics of the MPC members that influences voting behaviour. This supports the work of Besley et al. (2008), who note homogeneous reactions to inflation forecasts, and output gaps, with regards background characteristics of MPC members, and that inflation forecasts do a good job of predicting member behaviour. Similarly, Smales (2013) suggests that the decision-making behaviour of the Reserve Bank of Australia is related to the inflation-targeting framework within which the Bank operates.

A separate part of this literature focuses on the strategic and psychological factors affecting the behaviour of monetary policy committee members. Rülke and Tillmann (2011) study the extent of herding behaviour in FOMC member forecasts for growth, inflation and 
unemployment, and find no evidence of herding, while anti-herding is particularly important for non-voting members. The findings support the view that forecasts signal FOMC members' policy preferences. Claussen et al. (2012) emphasize the role of psychological factors, such as overconfidence, in monetary policy making. The factors are used to explain disagreements within committee members, the provision of decision power to those members, and the fact that chairmen of monetary policy committees rarely find themselves on the losing side of the committee vote. They theorise that the optimal influence of the chairman is related to the degree of overconfidence, and is limited when overconfidence is perceived to be a major issue. El-Shagi and Jung (2015), note evidence of coordination between Presidents of the Federal Reserve Districts that brings their voting preferences into line with the Fed Chair. Weise (2012) suggests that political considerations contributed to delays in tackling the rise in U.S. inflation in the 1970s.

In a recent paper, Nakazono (2013) attempts to investigate the strategic behaviour of each board member in the FOMC by using panel data on inflation forecasts provided by them prior to their semi-annual monetary policy report to the Congress. Their empirical findings display that FOMC members heavily rely on past forecasts when they submit their forecasts, with the average of their projections being rational. At the same time, forecasts by governors agree much with the previous consensus of FOMC members' forecasts, while this is not the case with non-governors whose forecasts deviate aggressively from the previous consensus. Overall, his results imply that these FOMC members behave strategically, in the sense that governors want to present policyconsistent forecasts to the Congress, while non-governors utilize their forecasts to influence monetary policy decision making.

The second strand of the literature is fundamentally associated with both the role of monetary rules in the central banks' decision process and the implication of the deviations from such a rule. Numerous types of monetary policy rules have been discussed in the literature, with such rules serving as benchmarks for policymakers in assessing the current stance of monetary policy and in determining a future policy path. The rule that has attracted the most attention is that of Taylor (1993), this rule states that the instrument of the monetary authority reacts to two key goal variables: deviations of contemporaneous inflation from a pre-set target rate and deviations of contemporaneous real output from its potential level. The Taylor Rule describes how central banks maintain low and stable inflation and avoid large fluctuations of output and 
employment by utilizing the intervention in the level of interest rates. The rule states that nominal interest rates react to the inflation deviation and the output gap, with the seminal contemporaneous rule specified as:

$$
\mathrm{r}=\mathrm{r}^{*}+\pi+0.5\left(\pi-\pi^{*}\right)+0.5 \mathrm{y}
$$

Where $r$ is the federal funds rate, $r^{*}$ is the equilibrium real interest rate, $\pi$ is the average of current inflation and the previous three-period inflation, $\pi^{*}$ is the inflation target, and $y$ is the output gap. The forward-looking Taylor rule describes how central banks respond to the expected inflation deviation as well as to the expected output gap. Among the forward-looking rules, the most prominent is that proposed by Clarida et al.(1998; 2000):

$$
\mathrm{it}^{*}=\mathrm{i}^{*}+\beta\left[\mathrm{E}\left(\pi_{\mathrm{t}+\mathrm{n}}\right)-\pi^{*}\right]+\gamma \mathrm{E}\left(\mathrm{y}_{\mathrm{t}+\mathrm{q}}\right)
$$

Eq. (2) is considered within an inflation targeting framework in the instance that the expected output gap can be treated as pressure on future inflation. Given the expected output gap, when the expected inflation rate is higher than the inflation target, the nominal rate is expected to increase and this will reduce investment and consumption expenditures by firms and individuals respectively, leading to reduced aggregate demand and, consequently, to lower inflation. Therefore, a Taylor rule can provide a nominal anchor for the central bank to react to various shocks, as well as providing an automatic stabilizer for the macroeconomy.

An extant literature utilizes the Taylor Rule to evaluate the efficacy of a central bank's decision making process (Nikolsko-Rzhevskyy, 2011; Ferrero, 2012; Givens, 2012; Taylor, 2012;among others). This literature demonstrates that this simple rule, or close variations of it, approximate the policy decisions of several major central banks. Moreover, empirical evidence (McCallum and Nelson, 1999; Rudebusch and Svensson, 1999) appears robust to replacing current data with lagged data owing to the persistence of inflation and output measures.

Carlstrom and Fuerst (2003) note that the Taylor rule has had a big impact in the way the FOMC implements monetary policy, although they recognize that it is not used (or should be used) as a mechanical rule but instead as a guide-post for monetary policy. This serves to enhance the central bank's credibility in fighting persistent deviations from a target inflation rate, and allows for deviations from the prescribed rule when economic conditions call for it. Batini and Haldane (1999) make the reasonable claim that the central bank has more information about the state of the economy at the time of decision making than is captured by inflation and output data 
alone, and it is also sensible to assume that authorities make policy decisions based on expected future economic conditions.

For this reason, a number of researchers prefer forward-looking, or forecast-based, policy rules in place of contemporaneous Taylor Rule methodology. Batini and Haldane (1999) show that forward-looking rules serve as stabilizing mechanisms to counter-balance the backwardlooking behaviour of the private sector. However, there is not clear empirical evidence in support of forecast-based rules. Rudebusch and Svensson (1999) find forecast-based rules only marginally outperform the contemporaneous rule. While Taylor (2000) notes that as long as forecasts are not too far into the future they will be very close to their contemporaneous counterparts.

There are several reasons why policy may occasionally deviate from monetary rules. Liquidity crises that require a temporary injection of reserves by the central bank represent one reason why it might be desirable to temporarily lower the policy rate below the level prescribed by a simple rule. Another reason for deviating from rule-like behaviour might be a shock to the aggregate price level. Such a shock might normally call for a tightening of policy, but if the shock is seen as transitory, with no impact on inflation expectations, it might not require the response prescribed by a rule. Finally, policymakers may respond to economic indicators other than those incorporated in the simple rule. In short, a simple rule may simply not capture all of the contingencies that might confront policymakers (Taylor, 1993; 2008). Overall, the lack of flexibility is the main reason why central banks are reluctant to commit to a policy rule. As long as shocks to the economy are frequent and unpredictable, central banks need the flexibility to implement and communicate their monetary policy away from a pre-specified rule.

\section{Data}

\section{FOMC Member Characteristics}

Our analysis covers the period from August 1979 to February 2014. This period runs from the appointment of Paul Volcker as FOMC Chair in August 1979, through the tenure of Alan Greenspan starting in August 1987, and covering the two terms of Ben Bernanke (February 2006 February 2014). The Federal Open Market Committee (FOMC) consists of twelve members; the seven members of the Board of Governors of the Federal Reserve system, the president of the Federal Reserve Bank of New York, and four of the remaining eleven Reserve Bank presidents who serve one-year terms on a rotating basis. The sample includes 3,226 voting observations, for 
87 members, over 294 FOMC meetings held during this period. Our key concerns involve understanding which idiosyncratic characteristics of FOMC members are important in the FOMC decision-making process, what drives deviations from a benchmark monetary policy rule ${ }^{2}$, and the likelihood of dissent by individuals from the policy decision.

Whilst our paper does not present an explicit theory of the formation of monetary policy, it does recognize that individuals' preferences are likely to have been moulded as they were educated and as they pursued careers prior to serving on the FOMC. We compile a novel database based on a number of personal characteristics of the FOMC members using official biographies ${ }^{3}$. The demographic characteristics that we consider include age, gender, and education level. In addition, Havrilesky and Schweitzer (1990) and Chappell et al. (1995) identify the importance of capturing work experience variables; they suggest that career proximity to central government may be more associated with expansionary monetary policy, while training as an economist may be associated with preferences for tighter policy. The work experience profile of each FOMC member is captured with a series of dummy variables indicating experience as an academic, in government, or in industry.

Finally, we capture a number of variables related to the nature of the appointment to the FOMC. Chappell et al. (1993) argue that monetary policy preferences systematically vary by political party; we seek to capture this using a dummy variable indicating the party of the President at the time appointment is made to the FOMC. Havrilesky and Gildea $(1992,1995)$ note that Governors are based in Washington D.C. and are reliant on the Chair for staff support. In contrast, the regional Bank Presidents have their own research staff and other resources at their proposal which may promote independence; a dummy variable indicating whether the FOMC member is a Governor is introduced to capture whether this has an impact on voting behaviour. Despite the fact the FOMC decision is made by majority rule, it is readily apparent that the Chair, along with other senior FOMC members, has a disproportionate influence on the policy process (Chappell et al., 2004); we introduce dummy variables for the Chair and Vice-Chair, along with the tenure of the Chair. The length of time served at the Federal Reserve, or on the FOMC, may also be important; it is possible that the longer time that Members spend working within the same organisation, or in the same role, the more likely they are to engage in group-think and not seek

\footnotetext{
${ }^{2}$ We utilise both current period and forward-looking versions of the Taylor Rule as a benchmark.

${ }^{3}$ The website of the Federal Reserve contains biographies for all members of the FOMC and Board of Governors since 1914: http://www.federalreserve.gov/aboutthefed/bios/board/boardmembership.htm
} 
to dissent from the group decision, alternatively it may be that longer tenure provides the confidence to take independent views. A full list of variables, with descriptions, is reported in Table 1.

\section{$<$ Insert Table 1>}

\section{FOMC Decision and Macroeconomic Characteristics}

A key feature of our analysis is the consideration of both the monetary policy decision announced by the FOMC, and also the voting behaviour underlying that decision. In the first instance, we consider the ordered decision to decrease rates, leave rates unchanged, or increase rates, before investigating deviations of policy decisions from a benchmark policy rule. Finally, we contemplate the voting behaviour in terms of dissent from the announced decision. We manually extract voting data from the FOMC's Record of Policy Actions ${ }^{4}$. For each FOMC meeting, the Record documents individuals' votes on the proposed monetary policy directive. By the time a formal vote is taken, majority support has already been assured, but members can and do register dissent $t^{5}$. Based on the description in the Record, we classify votes as assents, dissent favouring more expansionary (easier) policy, dissent favouring less expansionary (tighter) policy, and dissent based on the language expressed in the statement. A FOMC member may vote for no change or a(n) decrease (increase) in the interest-rate but still be classed as dissenting for easier (tighter) policy if the rate chosen by the FOMC is higher (lower) than their chosen rate.

In addition to the Fed Fund target rate following the FOMC decision, we consider deviations of the Fed Fund target from a benchmark nominal interest rate suggested by the Taylor (1993) Rule ${ }^{6}$, and determined using eq.(1) and eq.(2). A number of variables are also introduced to describe the macroeconomic conditions at the time of the FOMC meeting; economic growth represented by GDP, inflationary pressures characterized by the GDP deflator, and market expectations of future interest rates denoted by the slope of the yield curve. The macroeconomic data is obtained from Bloomberg in "real-time", that is, we use data that the FOMC members

\footnotetext{
${ }^{4}$ Detailed transcripts and other information surrounding the FOMC decision making process can be found on the Federal Reserve website: http://www.federalreserve.gov/monetarypolicy/fomc historical.htm

${ }^{5}$ The Chair has never dissented from a proposed directive, and Chappell et al. (1995) report that no directive has ever been defeated.

${ }^{6}$ We consider both current period and forward-looking versions of the Taylor Rule and find no qualitative difference in our results.
} 
would have possessed at the time that the relevant meeting was held (and monetary policy decision made $)^{7}$.

Summary statistics are reported in Table 2. Panel A shows that the Federal Funds target rate has averaged 5.75\% over the sample period, with a high of 19.5\% occurring in December 1980, and a low of $0.125 \%$ (the mid-point of the $0-0.25 \%$ range) prevailing from December 2008 until the end of the sample. Interestingly, while the deviations from the benchmark nominal interest rate implied by the Taylor Rule have been significant at times (up to 634b.p.) on average the deviation has been just $6 \mathrm{~b} \cdot \mathrm{p}^{8}$. The average age of a FOMC member is nearly 57 years, with the youngest, Kevin Warsh, at 36 years when appointed to the Board of Governors, and the oldest was Alan Greenspan who was approaching his $80^{\text {th }}$ birthday upon leaving the FOMC. The average length of time within the Federal Reserve System is a little over 16 years, average time since appointment to a senior FOMC position is $5 \frac{1}{2} 2$ years, and the mean tenure of the Chair approaches 7-years.

\section{$<$ Insert Table 2>}

Panel B reveals how the FOMC member characteristics have changed over time. The proportion of FOMC members educated to doctorate level has increased since Alan Greenspan was appointed to the Chair. While the proportion of female FOMC members has increased in recent times the reported figure still equates to less than three women taking part in each FOMC vote. The work experience of FOMC members has remained relatively constant over time in terms of academics $(\approx 50 \%)$ and prior experience in government roles $(\approx 95 \%)$ but the proportion of members with industry experience has declined to just $40 \%$ under Ben Bernanke. Reflecting the changing political environment, the number of appointees by the Republican Party increased from $21 \%$ to $70 \%$ during the tenure of Alan Greenspan before falling back to $40 \%$ more recently.

Finally, descriptive statistics illustrate that the Fed Funds Target was much higher on average (11.83\%), while Volcker was FOMC Chair as the Federal Reserve battled inflation, lower while Greenspan was in situ (4.81\%), and lowest under Bernanke (1.50\%), following the financial crisis of 2008-09. Deviations from the Taylor rule suggest that policy was more restrictive than the benchmark under Volcker, close to neutral during Greenspan's tenure, and expansive for

\footnotetext{
${ }^{7}$ The timing of information is important; Orphandides (2001) notes that policy recommendations using real-time data differ substantially from those obtained using ex-post revised data.

${ }^{8}$ The maximum difference is greater using a forward-looking Taylor rule.
} 
Bernanke's stewardship. Focusing on the FOMC target rate decisions (Panel C) it is apparent that leaving rates unchanged is the most prevalent outcome (53\% of decisions), with decisions also tending to be autocorrelated, where easing is followed by further easing and tightening is followed by further tightening; this is clearly evident in the evolution of the Fed Funds target rate depicted in Figure 1.

$<$ Insert Figure 1 - Evolution of Fed Funds Rate>

\section{Empirical Results}

\section{Factors influencing the FOMC Decision}

The FOMC decision is viewed as the committee choosing from one of three mutually exclusive choices: to ease monetary policy (decrease the Fed Funds Target), leave monetary policy unchanged (no-change to the Fed Funds Target), or tighten monetary policy (increase the Fed Funds Target). A natural candidate for modelling such behaviour is the ordered logit model:

$$
\begin{gathered}
Z_{k t}^{*}=x_{k t}^{\prime} \beta+\varepsilon_{k t}, \\
Z_{k t}=-1 \quad \text { if } Z_{k t}^{*} \leq \gamma_{1}, \\
Z_{k t}=0 \quad \text { if } \gamma_{1}<Z_{k t}^{*} \leq \gamma_{2}, \\
Z_{k t}=+1 \quad \text { if } Z_{k t}^{*}>\gamma_{2}
\end{gathered}
$$

Where $Z_{k t}^{*}$ is a stacked vector of $-1 \mathrm{~s}, 0 \mathrm{~s}$ and $+1 \mathrm{~s}$ corresponding to the FOMC decision to ease, leave un-changed, or tighten monetary policy. $x_{k t}$ is a matrix containing FOMC member characteristics and macroeconomic controls, as independent variables, $\beta$ is a vector of parameter estimates, and $\varepsilon$ is the error term ${ }^{9}$.

Maximum likelihood estimates for the ordered logit specification are presented in Table 3. The specification in the first column contains only explanatory variables related to the make-up of the FOMC and shows that the length of time working within the Federal Reserve System (FED_JOIN) increases the likelihood of an increase in interest rates, while an increase in the proportion FOMC members appointed by a Republican administration $\left(P_{-} P A R T Y\right)$ reduces the likelihood of tighter monetary policy. We note this result is contrary to conventional wisdom and

\footnotetext{
${ }^{9}$ Throughout the empirical analysis in this paper, cluster robust standard errors (Rogers, 1993) are reported, with the individual member as the cluster. Analysis was also conducted based on the robust errors of Huber (1967) and White (1980) with qualitatively similar results noted.
} 
the extant literature (Chappell et al., 1993) which suggests that Democrats would prefer easier policy and Republicans tighter policy. However, much of the relevant prior literature focuses on an earlier sample period than we consider here. Our sample period witnesses a unique era with low levels of inflation generally accompanied by high productivity growth, and low levels of volatility in economic growth, creating an environment where Republican FOMC members are able to prioritise other goals. The negative EDUCATION coefficient indicates that as the level of education of FOMC members increases (from Bachelors to Doctorate level) there is an increased propensity to reduce interest rates.

\section{$<$ Insert Table 3>}

Augmenting this initial specification with the introduction of macroeconomic variables (column 2), renders the aforementioned results insignificant and reveals that prior experience in Government work (GOVT) and length of tenure by the Fed Chair (CHAIR_TIME) are particularly important characteristics in determining the FOMC decision; the other FOMC member characteristics are no longer well-defined. A greater proportion of experience in Government is significantly more likely to produce a vote to decrease interest rates (or alternatively less likely to increase rates). As the Chair's tenure increases there is an increase in the likelihood of FOMC easing (a significant and negative coefficient), consistent with the idea that the Chair will not need to display inflation fighting credentials to the market as the time in office increases ${ }^{10}$. Notably, the Board of Governors (BOG) coefficient is not well-defined and this is in contrast with the results of Chappell and McGregor (2000) who note that Governors have a significant tendency to ease rates.

Results for the macroeconomic variables support the notion that the FOMC attempts to stabilize the business cycle. The positive and significant coefficient for GDP Growth and INFLATION suggest that monetary policy was tightened as output growth accelerated and eased when it slowed. Consistent with observed behaviour in the bond markets, monetary policy is tightened (eased) following a steepening (flattening) in the yield curve ( $\left.Y L D_{-} C\right)$. The identified results remain when a lagged deviation from the Taylor Rule (1993), $\operatorname{Lag}\left(D_{-} T A Y L O R\right)$, is introduced (column 3). Importantly, larger, persistent and positive (negative) deviations from the

\footnotetext{
${ }^{10}$ The 'inflation-fighting credentials' of the FOMC, and the Chair in particular, are often a focus of media speculation that in turn may feed into financial market speculation. For instance: http://blogs.wsj.com/economics/2013/05/12/most-economists-back-yellens-inflation-fighting-credentials/
} 
nominal interest rate implied by the Taylor Rule result in an increased likelihood of monetary policy tightening (easing). The coefficients for the cut-points between decision choices $\left(\gamma_{1}^{1}\right.$ and $\left.\gamma^{2}\right)$ indicate that a higher (lower) threshold is required to increase (decrease) the Fed Funds target.

\section{Policy deviations from the Taylor Rule}

So far, we have been able to identify characteristics of FOMC members that may lead to a propensity to increase or decrease the Fed Funds target, but without having a clear picture of the relative level of interest rates vis-à-vis a monetary policy rule. Having identified in the previous section that deviations from the Taylor Rule play a significant role in explaining changes in the level of monetary policy, in this section we seek to determine whether the characteristics of the FOMC board play a role in such deviations, and relate this to the relative level of monetary policy 'tightness'. We perform panel regressions with deviations of the Federal Funds target rate from the Taylor Rule as the dependent variable. As a robustness check, we use an alternate forwardlooking specification of the rule that incorporates GDP and GDP deflator (inflation) forecasts obtained from the Organisation for Economic Cooperation and Development (OECD). A panel regression model, of the following specification is used:

$$
D \_T A Y L O R_{t}^{*}=x_{k t}^{\prime} \beta+\varepsilon_{t} \text {, }
$$

Where D_TAYLORt refers to the deviation from the benchmark Taylor rule following the FOMC decision at meeting $t, x_{k t}$ is a matrix containing FOMC member characteristics, and macroeconomic controls, as independent variables, and $\beta$ is a vector of parameter estimates.

Empirical results for current period Taylor Rule are presented in columns $1 \& 2$ of Table 4 . The highly significant, and positive, constant indicates that on average the FOMC has preferred to err on the side of caution and maintained monetary policy above the level suggested by the Taylor Rule. The tenure of the Chair and FOMC members, along with time-served within the Federal Reserve System appear to have contrasting influences on monetary policy. As the length of time the Chair has been in position increases, deviations from the Taylor Rule are allowed to become more negative, again consistent with the notion that once the Chair has established inflation fighting credentials it is possible for more expansionary monetary policy than otherwise; a similar argument may be presented to explain the negative and significant coefficient for appointees to the FOMC (FOMC_APPT). Supportive of Göhlmann and Vaubel (2007), as the time-served on the 
central bank staff increases there is a greater preference for lower levels of inflation, in this case exhibited by monetary policy that is tighter than that suggested by the Taylor Rule.

$<$ Insert Table 4>

Consistent with Chappell et al. (1993), FOMC members nominated by a Republican President favour tighter monetary policy, demonstrated by the positive and significant coefficient of $P_{-} P A R T Y$. The well-defined, negative co-efficient for the GREENSPAN (indicating Alan Greenspan was Chair at the time of the specific meeting) and BERNANKE (indicating Ben Bernanke was Chair at the time of the specific meeting) and VCHAIR dummies reflect the observation that in more recent times (under the stewardship of Ben Bernanke as Chair, and Timothy Geithner as Vice-Chair) the Fed Funds Target has been kept well below that suggested by the Taylor Rule. There seems to be a slight predilection for female FOMC members (GENDER), and (consistent with Havrilesky and Gildea, 1995; Chappell and McGregor, 2000), Governors $(B O G)$ to prefer easier policy than Federal Reserve Presidents, however age, prior work experience, and education level, do not appear to play a role in explaining policy deviations from the Taylor Rule. The well-defined, negative, lagged dependent variable indicates that the FOMC acts to correct prior deviations from the Taylor Rule. The qualitative implications of our results are robust to the alternate, forward-looking, Taylor Rule specification presented in columns $3 \& 4$ of Table 4 .

\section{Dissent from the FOMC Decision}

So far the empirical analysis has focused on the outcome of FOMC decisions and how the decision might deviate from the nominal interest rate suggested by the Taylor Rule. We now attempt to gain an understanding into the factors which may lead to a FOMC member dissenting from the group decision. We consider a series of binary ${ }^{11}$ logit panel models of the form:

\footnotetext{
${ }^{11}$ An alternative approach would be to use an ordered logit framework. We use the binary logit framework as it provides greater simplicity, and by splitting the analysis of the decision into a two-stage process, allows for an understanding of the factors behinds the particular dissent decision (e.g. prefer easier policy, prefer tighter policy, or prefer different language). In addition, using ordered logit creates an issue in determining the appropriate order of choices to use. For example, we could assign "decision to dissent in favour of easier policy" as 0 , "no dissent" as 1 , and "dissent in favour of tighter policy as 2 . However, this ordering is questionable and creates problems with interpretation. In addition, there is no satisfactory way to include "dissent related to language employed in the statement" which could also be related to any of the three other choices.
} 


$$
\begin{gathered}
Z_{k t}^{*}=x_{k t}^{\prime} \beta+\varepsilon_{k t}, \\
Z_{k t}=0 \quad \text { if } Z_{k t}^{*} \leq \gamma_{1}, \\
Z_{k t}=+1 \quad \text { if } Z_{k t}^{*}>\gamma_{1}
\end{gathered}
$$

Where $Z_{k t}^{*}$ is a stacked vector of $0 \mathrm{~s}$ and +1 s corresponding to an individual FOMC member's decision to dissent from the group decision, $x_{k t}$ is a matrix containing FOMC member characteristics and macroeconomic controls, as independent variables, and $\beta$ is a vector of parameter estimates. A similar specification with the member's expressed preference for tighter or easier policy (or different policy language) as the decision variable allows for a more nuanced examination of the issue of dissent.

$<$ Insert Table 5>

Maximum likelihood estimates for the specified model are presented in Table 5. Columns 1 and 2 present the estimates for FOMC member dissent from the policy decision. Contrary to Havrilesky and Gildea (1992) working in academia significantly increases the likelihood of dissent, while working in Government or industry has no significant impact. The length of time since joining the Fed also increases the likelihood of dissent, perhaps explained by longer-serving Fed members having a greater level of support inside the institute and so been more comfortable in registering a dissenting vote. The probability of dissent declines as the tenure of the Chair increases, consistent with Krause (1994) and Chappell et al. (2004) who note that it is possible the Chair has the power to influence decisions and this may increase over time. El-Shagi and Jung (2015) also note that a strong Chair (such as Greenspan) may be able to enforce consent. The lagged dependent variable (column 2) demonstrates that there is some persistence in the propensity to dissent; i.e. a FOMC member dissenting in one meeting is more likely to dissent in the following meeting.

The remaining columns of Table 5 explore the decision to dissent further, focusing on dissent in favour of tighter monetary policy (column 3), easier monetary policy (column 4), and a preference for different language (column 5). Whilst the tendency for Governors to ease identified by Chappell and McGregor (2000) is not confirmed, there is at least evidence that a Governor would be significantly less likely to prefer tighter monetary policy. Consistent with the results in the previous section, and with Göhlmann and Vaubel (2007), long serving Federal 
Reserve staff prefer tighter monetary policy (and lower inflation rates). As a Chair is in place for a longer period the probability of dissent for tighter policy decreases (there is no significant impact on easier policy choices), this suggests that FOMC members become less concerned about inflation-fighting credentials as the Chair gains experience in the role. There is also less likely to be dissent in terms of monetary policy language as the tenure of the Chair increases, perhaps as the other FOMC members become more comfortable with the policy suggestions of the Chair. Academics and, to a lower degree of significance, those with experience in the government are more likely to dissent in favour of easier monetary policy. Macroeconomic variables significantly increase the likelihood of dissent in favour of easier policy, and for different language, this is likely because FOMC members have different opinions as to the potential for the economic state to persist. Finally, the coefficient for the lagged dependent variable provides clear evidence that FOMC members continue to dissent once they have made the initial decision to do so.

\section{Robustness Tests}

\section{Evolving monetary policy regime}

So far, the analysis has effectively assumed that the monetary policy regime has remained constant throughout the sample period. It is possible that this is not the case, and that the determinants of policy decisions changed as the regime evolved. We investigate this by splitting our sample. In the first instance, we have the sample of meetings that occur during the period we denote as the Great Moderation; this runs from January 1982 - August 2007'12. Secondly, we have the sample of meetings within the period of the Great Recession \& aftermath (or Global Financial Crisis), which starts in August $2007^{13}$ with strain in mortgage markets and runs until the end of our sample period. While Clark (2009) suggests this period is merely a temporary period of high volatility, and not necessarily a definitive end to the Great Moderation, we include this period for as it witnessed a period of extraordinary monetary policy actions. During this period, the Fed Funds target rate moved close to zero, large scale asset purchases were undertaken, and quantitative easing introduced. Given such actions, it is naturally of particular interest to investigate whether our reported results remain relevant under such circumstances. Finally, we

\footnotetext{
12 This timeline is noted by the Federal Reserve History (http://www.federalreservehistory.org/Events/DetailView/65)

${ }^{13}$ Again, this follows the suggestion of the Federal Reserve History. Our results are qualitatively robust to changing the specific start date, with the Lehman Brothers collapse of September 2008 offering one alternative.
} 
consider a third period of zero interest rate policy (ZIRP) which starts following the December 2008 meeting, when the Fed funds target rate reached the zero lower bound. The target rate remained at this lower bound until the end of the sample period. We note the significant overlap with the second sub-sample but still feel this sample is worth considering given the nature of monetary policy decisions (no-change) throughout.

During the latter two sample periods, to achieve their monetary policy goals, the FOMC implemented two forms of unconventional policy. First, the use of forward guidance, whereby the FOMC attempted to reduce, and stabilise, longer-term interest rates by publically committing to maintaining the policy rate close to zero for an extended period of time. Evidence suggests this may have been ineffective in driving economic recovery (e.g. Anderson and Hoffman, 2010; Kool and Thornton, 2012). Second, the FOMC introduced Quantitative Easing (QE), where longerterm assets were purchased, in order to reduce long-term rates. Immediately following the announcement of Lehman's demise, primary credit borrowing and Term Auction Facilities (TAF) lending increased markedly. Evidence shows that these actions were appropriate (Thornton; 2010, 2012). The effectiveness of these actions is reflected in risk spreads, where both short- and longterm spreads, which had increased dramatically following Lehman's announcement, declined markedly. These actions indicate that even after the Fed Fund target rate reached the zero lowerbound the FOMC remained aggressive in its policy actions. The effectiveness of monetary policy actions comes through the expectations effect, which seems to be particularly important when the FOMC's actions occur at a time when there are significant signs that financial markets need stabilizing mechanisms.

Overall, the literature provides supportive evidence that monetary policy decisions after the crisis, involving asset purchases, were most effective at stimulating the economy when they work in concert with expectations of sustained easy conventional monetary policy (Chen et al., 2012; Chung et al., 2012). Based on the particular issues concerning the policy decisions of the FOMC during the post-crisis period, we expect that the demographic drivers, identified as significant in the previous sections of the empirical analysis, will not play a substantial (if any) role in influencing monetary policy decisions; whether this is manifested through deviations of policy from a benchmark Taylor rule or dissents by individuals from the committee decision.

Therefore, we repeat our earlier analysis with the sample disaggregated into the three subperiods already explained. Table 6 presents estimates for coefficients of the ordered logit 
regression specified in equation (5). Recall that for the whole sample period the member characteristics that had a significant effect on the FOMC decision where government service (GOVT) and tenure of the Chair (CHAIR_TIME). Disaggregating the sample shows that the same two characteristics still have a significant influence, and in the same direction, on the decision across all sub-periods. No other characteristics have an impact on the decision in the period subsequent to the Great Recession. Interestingly, during the Great Moderation, political party at time of Fed appointment, length of service within the Federal Reserve, and industry experience influence FOMC decisions, but this ceases to be the case in the subsequent periods. Macroeconomic variables influence the decision across all sample periods, but the direction of the relationship changes during the Great Recession; likely as members' priority shifts away from inflation fighting.

\section{$<$ Insert Table 6>}

Table 7 presents estimates for coefficients for the regression specified in equation (6), with the sample again disaggregated into three sub-periods. In the period prior to the Great Recession, deviations from the Taylor Rule are explained in much the same way as that highlighted earlier, and is also consistent with the evidence provided in Table 6. Appointments during a Republican Presidency and with longer tenure within the Federal Reserve System will tend to result in tighter policy than implied by the Taylor Rule (positive deviations), while increasing the tenure of the Chair, and appointment to the FOMC, will result in easier policy than is suggested (negative deviations). Deviations from the Taylor Rule tended to be more negative during Greenspan's tenure as Chair, then in the period of Volcker's tenure. The deviation was even greater for the brief part of the Great Moderation for which Bernanke was Chair ${ }^{14}$.

\section{$<$ Insert Table 7>}

In contrast, the period following the onset of the Great Recession produces very different results. First, using current period inputs, the constant is significantly negative, indicating that that monetary policy would be easier than that implied by the Taylor Rule, all else held constant. This compares with the Great Moderation period when the constant was significant and positive. Importantly, the Great Recession period sees Academic background become a significant factor on

\footnotetext{
${ }^{14}$ No GREENSPAN or BERNANKE dummy variable is included for the period subsequent to the Great Moderation as Bernanke was Chair for the whole period.
} 
deviations from the Taylor Rule, with the implication that a greater number of academics within the FOMC would result in easier policy during this period (more negative deviations). This is consistent with academic members of the FOMC, such as Bernanke (1983, 2004), spending part of their career analysing policy during the Great Depression and seeking to prevent a repeat by choosing accommodative policy. The only other FOMC member characteristic that has any significance is that of the time spent in situ by the Chair where the relationship is negative and significant, as it is for the whole sample; that is the effect of the Chair's tenure appears to be consistent throughout the sample.

\section{$<$ Insert Table 8>}

Disaggregating the data in a similar fashion also allows for further inspection of the decision to dissent from the vote, with the results reported in Table 8 . The influences of the identified factors on dissent from the majority vote indicate that there are some important differences. First, whereas tenure of the Chair is significant in the overall sample, and during the Great Moderation, this is no longer the case following the start of the Great Recession. Similarly, while length of time at the Fed significantly increases the likelihood of dissent during the Great Moderation, it has no significant effect in subsequent periods. Industry (Government) experience significantly increases (decreases) the likelihood of dissent during the Great Moderation, but the effect is reversed (although not well-defined) in the Great Recession period. In addition, Governors are more likely to dissent in the Great Recession. The lagged dependent variable is positive and significant in all sub-periods, indicating that having dissented at one vote, there is an increased likelihood of the member dissenting at the following vote.

We note that the tenure of Alan Greenspan (19-years), was significantly longer than that of either his predecessor, Paul Volcker (8-years), or his successor, Ben Bernanke (8-years), and also that the issues faced by each Chair was different. For instance, Volcker had to grapple with extremely high inflation, while Bernanke encountered a major financial crisis. This raises potential issues with the interpretation of variables relating to the tenure of the Chair. Analysing different sub-periods of the sample allows us to at least consider whether the effect was consistent across time. The empirical evidence does seem to suggest that the tenure of the Chair does have a consistent, and well-defined, effect on FOMC decisions. 
To summarize, the financial crisis that brought an end to the Great Moderation precipitated a change in the characteristics of FOMC members that influenced both the stance of monetary policy relative to a benchmark rule, and the propensity of individual members to dissent from majority vote. This coincided with a period of unconventional monetary policy with the Fed Funds target rate remaining close to zero for a prolonged period, and suggests that FOMC decision-making behaviour has adapted to circumstance.

\section{Defining member characteristics}

Many of the FOMC members have experience in more than one sector (ACADEMIC, GOVT, INDUSTRY) prior to appointment to the Fed. It possible that the decisions made by a member who has wider experience (for instance, as both an academic and in industry) are different to those with more narrow experience (in just one sector). We add interaction terms to each of our model specifications in order to examine this possibility. We also test whether the specification of EDUCATION is appropriate, introducing distinct dummy variables indicating an individual members highest level of education (since all members have a BACHELORS, the dummy variables chosen are MASTERS and DOCTORATE). Empirical results are presented within the Appendix (Appendix 1, Appendix 2, Appendix 3).

The main impact of changing this specification appears to lie in the member characteristics affecting the FOMC decision (Appendix 1) rather than deviations from the Taylor Rule or dissent. Two points are noted. First, the negative coefficient for EDUCATION shown in Column 1 of Table 3 appears to be due to DOCTORAL level education (although this effect disappears once macroeconomic variables are added). Second, the negative coefficient for FOMC members with government background noted in Table 3 is specific to those FOMC members who have experience in both academia and government. In all other cases, the interaction terms are not significant.

In our empirical analysis we introduced a dummy variable to indicate political partisanship along the lines of Chappell et al. (1993). Whereas that paper assigned political status only to members of the Board of Governors, we also apply the variable to presidents of the Federal Reserve districts. It is therefore useful to understand whether this decision has an impact on our reported results, and so we re-run our analysis. We find that results are qualitatively similar to 
that found with our original specification (for instance Appendix 1, Model 4), and so do not present the results here.

\section{Conclusions}

This paper has attempted to examine the influence of FOMC member characteristics on the monetary policy decision making process. We utilise a novel dataset to examine FOMC decisions, the effectiveness of those decisions, and individual dissent from the Committee decision, over the period July 1979 - February 2014.

Our empirical results show that education, age, and, to a lesser extent, work experience are not important in understanding the FOMC decision-making process; this is contrary to the extant literature for the FOMC (e.g. Chappell at al., 1995; Havrilesky and Gildea, 1995) but consistent with the work on the monetary policy committee of the Bank of England conducted by Harris et al. (2011). Instead, our results point to the importance of time spent within the Federal Reserve System, on the FOMC itself, and the influence of the Chair in shaping the decisionmaking process. Taken together, the results suggest that once the FOMC, and it's Chair, has established credibility to fight inflation, it is possible to target other objectives for monetary policy as set out in the Federal Reserve Act, for example "maximum employment".

Our findings also seem to be consistent with the extant literature (e.g. Chappell et al., 2004) in emphasising the importance of the FOMC Chair in influencing decisions; as tenure increases the likelihood of interest rate cuts grows, as does the prospect of policy being easier than that suggested by the Taylor Rule, while the instances of dissent from FOMC members declines. Disaggregating the data, into two sub-samples, reveals that the FOMC decision-making behaviour altered during the period of unconventional monetary policy that following the financial crisis of 2008.

The implications associated with our empirical results could be that economic agents and (financial) markets across the economy can increase their capacity to more accurately utilize the information disseminated from the central bank. This would significantly reduce the uncertainty associated with monetary policy decisions enable both economic agents and markets to attach the correct weight to the information emanating from monetary policy decisions. This is important since the presence of uncertainty about the merit and the drivers of FOMC members' decisions is welfare reducing. 
Building on the results of this paper, a key direction for future research would be to explore the predictive power of our modelling approach both when committee members care and do not about their reputation. Such reputational concerns can connect current monetary policy decisions to previous decisions, introducing a causal link from current to future policy choices. Therefore, empirically investigating this methodological strand is expected to be a key issue that is ripe for future research. It would be also highly interesting to extend the empirical model to other central banks, such as the Bank of England and the European Central Bank monetary policy committees.

$$
\begin{aligned}
& \text { <Insert Appendix 1> } \\
& \text { <Insert Appendix 2> } \\
& \text { <Insert Appendix 3> }
\end{aligned}
$$

\section{References}

Al-Marhubi F.A., 2004, The determinants of governance: A cross-country analysis, Contemporary Economic Policy, 2, 394-406.

Andersson, M., Hofmann, B., 2010. Gauging the effectiveness of central bank forward guidance. In Twenty Years of Inflation Targeting: Lessons Learned and Future Prospects, edited by David Cobham, Øyvind Eitrheim, Stefan Gerlach and Jan Qvigstad, Cambridge University Press, 368397.

Batini, N., Haldane, A.G., 1999, Forward-looking rules for monetary policy. In Taylor, J.B. (Ed.), Monetary Policy Rules. University of Chicago Press: Chicago.

Bernanke, B.S., 1983, Nonmonetary effects of the financial crisis in the propagation of the Great Depression, American Economic Review, 73, 257-276

Bernanke, B.S., 2004, Essays on the Great Depression, Princeton University Press.

Besley, T., N. Meads, and P. Surico, 2008, Insiders versus outsiders in monetary policymaking, American Economic Review, 98, 218-223

Blinder A.S., 2004, The quiet revolution: Central banking goes modern. Yale University Press. Blinder, A.S., 2007, Monetary policy by committee: Why and how? European Journal of Policitcal Economy 23, 106-123.

Blinder, A.S., 2009, Making monetary policy by committee, International Finance, 12, 171-194. Caporale, T., Grier, K.B., 2000, Political regime change and the real interest rate, Journal of 
Money, Credit, and Banking 32, 320-334.

Carlstrom, C.T., Fuerst, T.S., 2003, The Taylor rule: A guidepost for monetary policy? Federal Reserve Bank of Cleveland Economic Review.

Chappell, H.W., T.M. Havrilesky, and R.R. McGregor, 1993, Partisan monetary policies: Presidential influence through the power of appointment, Quarterly Journal of Economics, 108, 185-218.

Chappell, H.W., T.M. Havrilesky, and R.R. McGregor, 1995, Policymakers, Institutions, and Central Bank Decisions, Journal of Economics and Business, 47, 113-136.

Chappell, H.W., and R.R. McGregor, 2000, A long history of FOMC voting behaviour, Southern Economic Journal, 66, 906-922.

Chappell H.W. Jr., McGregor R.R., Vermilyea T.A. 2004. Majority rule, consensus building, and the power of the chairman: Arthur Bums and the FOMC. Journal of Money, Credit and Banking 36, 407-422.

Chappell H.W. Jr., McGregor R.R., Vermilyea T.A. 2014. Power-sharing in monetary policy committees: Evidence from the United Kingdom and Sweden. Journal of Money, Credit and Banking 46, 665-692.

Chen, H., Cúrdia, V., Ferrero, A., 2012. The macroeconomic effects of large-scale asset purchase programmes. The Economic Journal 122, F289-F315.

Chung, H., Laforte, J.P., Reifschneider, D., Williams, J.C. 2012. Have we underestimated the probability of hitting the zero lower bound? Journal of Money, Credit and Banking 44, 47-82.

Clarida, R., Gali J., Gertler, M. 1998. Monetary policy rules in practice: Some international evidence. European Economic Review, 42, 1033-1067.

Clarida, R., Gali, J., Gertler, M. 2000. Monetary policy rules and macroeconomic stability: Evidence and some theory. Quarterly Journal of Economics, 115, 147-180.

Clark, T.E., 2009, Is the great moderation over? An empirical analysis, Economic Review of the Federal Reserve Bank of Kansas City, Q4, 5-42

Claussen, C.A., Matsen, E., Røisland, Ø., Torvik, R. 2012. Overconfidence, monetary policy committees and chairman dominance. Journal of Economic Behavior and Organization 81, 699711.

El-Shagi, M., A. Jung, Does the Greenspan Era Provide Evidence for Leadership in the FOMC?, Journal of Macroeconomics, Vol. 44 (March 2015), pp. 173 - 190.

Eusepi, S., 2010. Central bank communication and the liquidity trap. Journal of Money, Credit 
and Banking 42, 373-397.

Ferrero, A., 2012. The advantage of flexible targeting rules. Journal of Money, Credit and Banking $44,863-881$,

Fischer S., 1994, Modern central banking. In F. Capie, C. Goodhart, S. Fischer, N. Schnadt, (Eds), The future of Central Banking. The tercentenary symposium of the Bank of England, Cambridge University Press, 262-308.

Fry, M., Julius, D.A., Mahadeva, L., Roger, S., Sterne, G., 2000, Key issues in the choice of monetary policy framework. In Monetary Frameworks in a Global Context, by L.Mahadeva and G. Sterne (Eds.), London: Routledge.

Gilchrist, S., and Leahy, J., 2002. Monetary policy and asset prices. Journal of Monetary Economics 49, 75-97.

Givens, G.E., 2012. Estimating central bank preferences under commitment and discretion. Journal of Money, Credit and Banking 44, 1033-1061.

Göhlmann, S., Vaubel, R., 2007, The educational and occupational background of central bankers and its effect on inflation: An empirical analysis, European Economic Review, 51, 925-941.

Harris, M.N., Levine, P., Spencer, C., 2011, A decade of dissent: Explaining the dissent voting behaviour of Bank of England MPC members, Public Choice, 146, 413-442.

Havrilesky, T., 1993, The Pressures on American Monetary Policy, Kluwer.

Havrilesky, T., 1994a, The political economy of monetary policy, European Journal of Political Economy, 10, 111-134.

Havrilesky, T., 1994b, Outside influences on monetary policy: A summary of recent findings, Contemporary Economic Policy, 12, 46-51.

Havrilesky, T.M., and J. Gildea, 1992, Reliable and unreliable partisan appointees to the Board of Governors, Public Choice, 73, 397-417.

Havrilesky, T.M., and J. Gildea, 1994, The relative importance of the Chairman in FOMC deliberations, Working Paper.

Havrilesky, T.M., and J. Gildea, 1995, The biases of Federal Reserve Bank Presidents, Economic Inquiry, 33, 274-284.

Havrilesky, T.M., and R. Schweitzer, 1990, A theory of FOMC dissent voting with evidence from the time series, In The Political Economy of American Monetary Policy (T. Mayer, ed.) New York: Cambridge University Press. 
Huber, P.J., 1967, The behaviour of maximum likelihood estimates under nonstandard conditions, Proceedings of the Fifth Berkeley Symposium on Mathematical Statistics and Probability, 1, 221233

King, M., 2005, Monetary policy: Practice ahead of theory. Mais Lecture, Bank of England Quarterly Bulletin.

King, R.G., Lu, Y.K. and Pasten, E.S., 2008. Managing expectations. Journal of Money, Credit and Banking 40, 1625-1666.

Kool, C.J.M., Thornton, D.L., 2012. How effective is central bank forward guidance? Utrecht School of Economics Discussion Paper Series 12-05.

Krause, G.A., 1994, Federal Reserve policy decision making: Political and bureaucratic influences, American Journal of Political Science, 38, 124-144.

Lamla, M.J. and Maag, T., 2012. The role of media for inflation forecast disagreement of households and professional forecasters. Journal of Money, Credit and Banking 44, 1325-1350.

Matsen E., Røisland Ø., 2005, Interest rate decisions in an asymmetric monetary union, European Journal of Political Economy, 21, 365-384.

McCallum, B.T., Nelson, E., 1999, Performance of operational policy rules in an estimated semiclassical structural model. In Taylor, J.B. (Ed.), Monetary Policy Rules. University of Chicago Press, Chicago.

Meade, E.E., Stasavage, D., 2008, Publicity of debate and the incentive to dissent: Evidence from the US Federal Reserve, Economic Journal, 118, 695-717.

Nakazono, Y., 2013, Strategic behavior of Federal Open Market Committee board members: Evidence from members' forecasts, Journal of Economic Behavior and Organization, 93, 62-70.

Nikolsko-Rzhevskyy, A., 2011. Monetary policy estimation in real time: Forward-looking Taylor rules without forward-looking data. Journal of Money, Credit and Banking 43, 871-897.

Orphanides, A., 2001, Monetary policy rules based on real-time data, American Economic Review, 91, 964-985

Riboni, A., Ruge-Murcia, F.J., 2010, Monetary policy by committee: Consensus, chairman dominance, or simple majority? The Quarterly Journal of Economics, 363-416.

Riboni, A., Ruge-Murcia, F.J., 2013, Dissent in monetary policy decisions, Journal of Monetary Economics, http://dx.doi.org/10.1016/j.jmoneco.2014.03.006.

Rogers, W.H., 1993, Regression standard errors in clustered samples, Stata Technical Bulletin, 13, $19-23$ 
Rosa, C., 2013. The financial market effect of FOMC minutes. Federal Reserve Bank of New York Policy Review, 1-15.

Rudebusch, G.D., Svensson, L.E.O., 1999, Policy rules for inflation targeting. In Taylor, J.B. (Ed.), Monetary Policy Rules. University of Chicago Press: Chicago.

Rülke, J.C., Tillmann, P., 2011, Do FOMC members herd? Economics Letters 113, 176-179.

Sack, B., Wieland, V., 2000, Interest-rate smoothing and optimal monetary policy: A review of recent empirical evidence. Journal of Economics and Business, 52, 205-228.

Sibert A., 2005, Is the structure of the ECB adequate to the new challenge? In F. Breuss and E. Hochreiter, (Eds), Challenges for Central Banks in an enlarged EMU, Springer, 95-118.

Smales, L.A., 2013. The determinants of RBA target rate decisions: A choice modelling approach. The Economic Record 89, 556-569.

Taylor, J.B., 1993, Discretion versus policy rules in practice, Carnegie-Rochester Conference Series on Public Policy, 39, 195-214.

Taylor, J.B., 2000, Alternative views of the monetary transmission mechanism: What difference do they make for monetary policy? Oxford Review of Economic Policy, 16, 60-73.

Taylor, J.B., 2008, The costs and benefits of deviating from the systematic component of monetary policy. Keynote address at the Federal Reserve Bank of San Francisco Conference on 'Monetary Policy and Asset Markets'.

Taylor, J.B., 2012. Monetary policy rules work and discretion doesn't: A tale of two eras. Journal of Money, Credit and Banking 44, 1017-1032.

Thornton, D.L., 2012. The Federal Reserve's response to the financial crisis: What it did and what it should have done. Federal Reserve Bank of St. Louis Working Paper 2012-050A.

Thornton, D.L.2010. The unusual behavior of the federal funds rate and Treasury yields: A conundrum or an instance of Goodhart's law? Federal Reserve Bank of St. Louis Working Paper 2007-039C.

Weise, C.L., 2012, Political pressures on monetary policy during the US Great Inflation. American Economic Journal: Macroeconomics 4, 33-64.

White, H., 1980, A heteroskedasticity-consistent covariance matrix estimator and a direct test for heteroskedasticity, Econometrica, 48, 817-830 


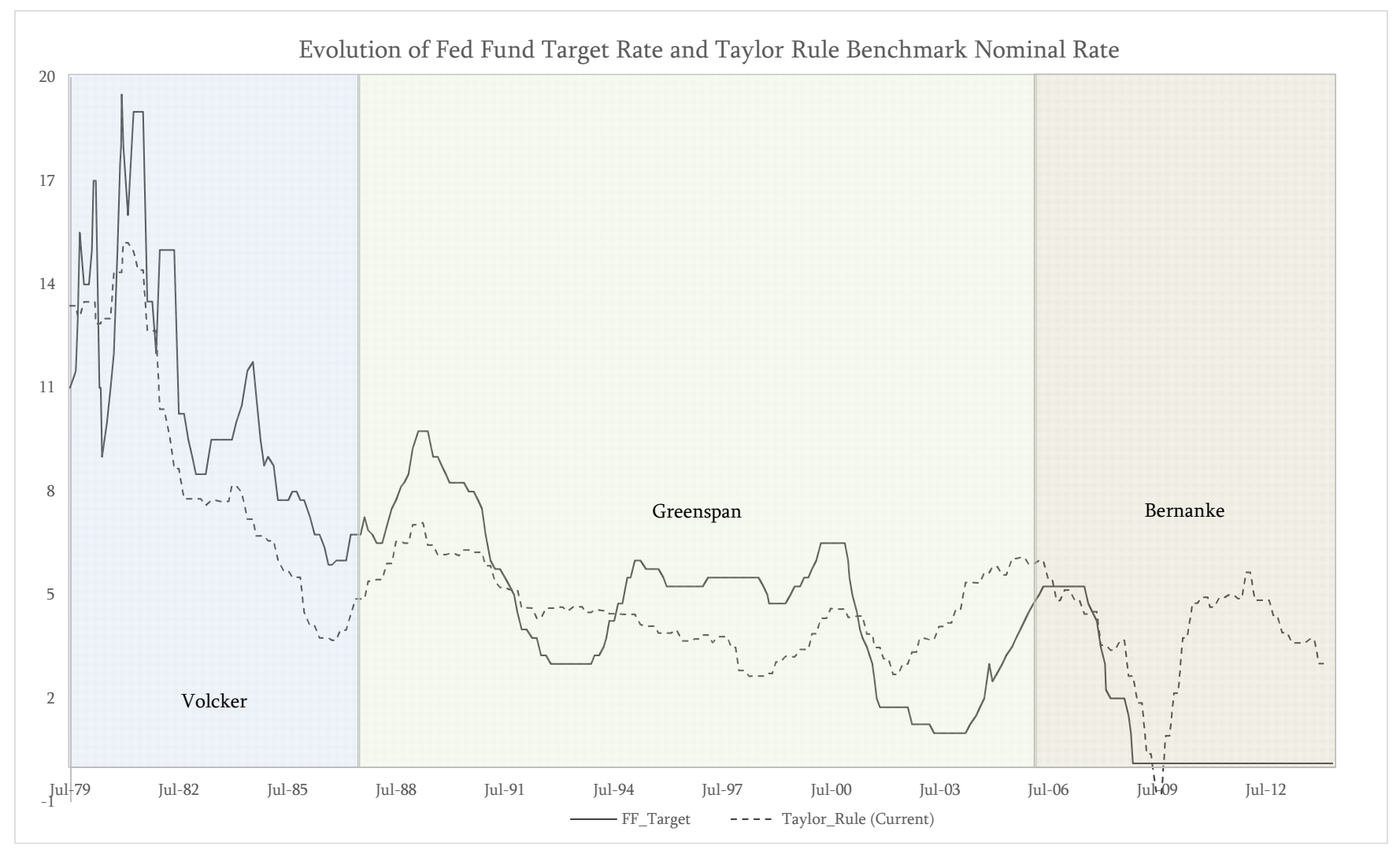

Figure 1 
Table 1

Description of Variables

Panel A: Variables Describing FOMC Members' Characteristics

\begin{tabular}{ll}
\hline Variable & Definition \\
\hline AGE & Age (in years) of member at time of meeting \\
GENDER & Dummy variable equal to 1 if the member is female; otherwise equal to zero. \\
EDUCATION & Dummy variable equal to 2 if the member has a Ph.D. degree, 1 if the member has a MA degree; otherwise equal to zero. \\
MASTERS & Dummy variable equal to 1 if the member's higest level of education is a Masters degree; otherwise equal to zero. \\
DOCTORATE & Dummy variable equal to 1 if the member's higest level of education is a Doctorate; otherwise equal to zero. \\
ACADEMIC & Dummy variable equal to 1 if the member has work experience as an academic; otherwise equal to zero. \\
GOVT & Dummy variable equal to 1 if the member has work experience in government; otherwise equal to zero. \\
INDUSTRY & Dummy variable equal to 1 if the member has work experience in industry; otherwise equal to zero. \\
P_PARTY & Dummy variable equal to 1 if the member was appointed by a Republican administration; otherwise equal to zero. \\
BOG & Dummy variable equal to 1 if the member is appointed to the Federal Reserve Board of Governors; otherwise equal to zero. \\
CHAIR & Dummy variable equal to 1 if the member was Chair of the FOMC at given meeting; otherwise equal to zero. \\
VICE_CHAIR & Dummy variable equal to 1 if the member was Vice-Chair of the FOMC at given meeting; otherwise equal to zero. \\
D_CHAIR & Variable indicating FOMC Chair at time of meeting; $0=$ Volcker, $1=$ Greenspan, $2=$ Bernanke \\
GREENSPAN & Dummy variable equal to 1 if Alan Greenspan was Chair of the FOMC at given meeting; otherwise equal to zero. \\
BERNANKE & Dummy variable equal to 1 if Ben Bernanke was Chair of the FOMC at given meeting; otherwise equal to zero. \\
D_VCHAIR & Variable indicating FOMC Vice-Chair at time of meeting; $0=$ Solomon, 1 = Corrigan, $2=$ McDonough, $3=$ Geithner, $4=$ Dudley \\
FOMC_APPT & Years since member was appointed to role on Board of Governors or senior Federal Reserve position (e.g. President of Federal F \\
FED_JOIN & that entitled member to be part of FOMC. \\
CHAIR_TIME & Years since member first joined the Federal Reserve system in any capacity. \\
\hline
\end{tabular}

Panel B: Variables Describing Decision Characteristics

\begin{tabular}{ll}
\hline Variable & Definition \\
\hline DEC_2 & $\begin{array}{l}\text { Dummy variable equal to } 1 \text { if the Fed Funds target was changed at the meeting; otherwise equal to zero. } \\
\text { DEC_3 }\end{array}$ \\
DISSENT & $\begin{array}{l}\text { Ordered decision variable equal to }-1 \text { if the Fed Funds target was decreased at the meeting, }+1 \text { if the Fed Funds target was incre: } \\
\text { the meting; otherwise equal to zero. }\end{array}$ \\
TIGHTER & $\begin{array}{l}\text { Dummy variable equal to } 1 \text { if the member dissented from the overall decision at the meeting; otherwise equal to zero. } \\
\text { equal to zero. }\end{array}$ \\
EASIER & $\begin{array}{l}\text { Dummy variable equal to } 1 \text { if the member preferred more expansive (easier) monetary policy than decided by the FOMC; other } \\
\text { equal to zero. }\end{array}$ \\
LANGUAGE & Dummy variable equal to 1 if the member dissented on grounds of language in policy statement; otherwise equal to zero.
\end{tabular}

FF_TARGET Fed Fund Target rate resulting from meeting decision. If a specific target is not provided then the mid-point of the target range

TAYLOR

D_TAYLOR

GDP

INFLATION

YLD_CURVE

Benchmark nominal interest rate determined by Taylor rule. Calculated as per Taylor (1993), with output measured by the loga real GDP, the logarithm of potential output measured by the 5-year rolling average of real GDP, the rate of inflation measured GDP deflator, the desired rate of inflation set equal to $2 \%$, the assumed equilibrium real interest rate equal to $2 \%$. Robustness cl consider an alternate version replacing current levels of growth and inflation with estimates obtained from the OECD.

Note: This table describes the main variables used within the empirical framework of this paper. 
Table 2

Summary Statistics

\begin{tabular}{lcccc}
\hline Panel A: Whole Sample & MEAN & ST. DEV & MIN & MAX \\
\hline FF_TARGET & 5.75 & 4.41 & 0.125 & 19.50 \\
TAYLOR (Current) & 5.69 & 3.12 & -0.75 & 15.20 \\
D_TAYLOR (Current) & 0.06 & 2.48 & -5.53 & 6.34 \\
TAYLOR (Forward-Looking) & 5.71 & 3.10 & 0.92 & 15.26 \\
D_TAYLOR (Forward-Looking) & 0.04 & 3.04 & -6.25 & 9.64 \\
AGE & 56.79 & 7.80 & 35.98 & 79.96 \\
FED_JOIN & 16.21 & 12.80 & 0.00 & 45.00 \\
FOMC_APPT & 5.53 & 4.49 & 0.00 & 23.76 \\
CHAIR_TIME & 6.98 & 5.44 & 0.00 & 19.47 \\
\hline Panel B: Mean values under & & & & \\
different FOMC Chair & Overall & Volcker & Greenspan & Bernanke \\
\hline EDUCATION & 1.61 & 1.44 & 1.67 & 1.65 \\
GENDER & 0.14 & 0.11 & 0.12 & 0.24 \\
ACADEMIC & 0.47 & 0.52 & 0.44 & 0.52 \\
GOVT & 0.94 & 0.95 & 0.93 & 0.97 \\
INDUSTRY & 0.63 & 0.66 & 0.71 & 0.40 \\
P_PARTY & 0.56 & 0.21 & 0.70 & 0.59 \\
FF_TARGET & 5.75 & 11.83 & 4.81 & 1.50 \\
D_TAYLOR (Current) & 0.06 & 1.80 & 0.27 & -2.41 \\
D_TAYLOR (Forward-Looking) & 0.04 & 2.17 & 0.04 & -2.30 \\
\hline
\end{tabular}

Panel C: Transition Table of FOMC Decisions

\begin{tabular}{r|ccc} 
DEC_3 & Cut $(-1)$ & No-Change (0) & Hike $(+1)$ \\
\hline Cut (-1) & 55.6 & 36.48 & 7.92 \\
No-Change (0) & 16.2 & 71.92 & 11.87 \\
Hike (+1) & 9.44 & 27.29 & 63.27 \\
\hline Total & 24.22 & 53.35 & 22.43
\end{tabular}

Note: This table provides summary statistics for the main variables used in this study. FF_TARGET is the Fed Funds Target rate decided at the FOMC meeting, TAYLOR is the benchmark nominal interest rate calculated using the Taylor Rule (utilising both current period and forward-looking growth and inflation data), and $D \_T A Y L O R$ refers to deviations of the FF_TARGET from this benchmark rate. $A G E$ is the age (in years) of the FOMC member while EDUCATION and GENDER $(0=\mathrm{M}, 1=\mathrm{F})$ are dummy variables reflecting other FOMC member characteristics. ACADEMIC, GOVT, and INDUSTRY are dummy variables indicating prior work experience of the FOMC member, and $P \_P A R T Y$ is a dummy variable indicating the party of the President nominating the member to the FOMC ( 0 = Democrat, $1=$ Republican $)$. Panel $\mathrm{B}$ denotes how the mean of relevant variables has changed over time. Panel $\mathrm{C}$ is a transition table of FOMC decisions indicating the proportion of occasions on which one choice of ordered monetary policy decision (to cut, leave rates unchanged, or hike rates) has followed another. 
Table 3

Ordered Logit: Factors influencing the FOMC Decision

\begin{tabular}{|c|c|c|c|c|c|c|}
\hline $\begin{array}{l}\text { Dependent Variable: } \\
\text { FOMC decision }\end{array}$ & (1) & & (2) & & (3) & \\
\hline$\overline{\mathrm{AGE}}$ & $\begin{array}{l}-0.001 \\
(0.005)\end{array}$ & & $\begin{array}{l}0.004 \\
(0.005)\end{array}$ & & $\begin{array}{l}-0.001 \\
(0.006)\end{array}$ & \\
\hline EDUCATION & $\begin{array}{l}-0.180 \\
(0.068)\end{array}$ & ${ }^{* * *}$ & $\begin{array}{l}-0.080 \\
(0.070)\end{array}$ & & $\begin{array}{l}-0.046 \\
(0.070)\end{array}$ & \\
\hline P_PARTY & $\begin{array}{l}-0.260 \\
(0.072)\end{array}$ & ${ }^{* * *}$ & $\begin{array}{c}0.000 \\
(0.075)\end{array}$ & & $\begin{array}{c}0.074 \\
(0.076)\end{array}$ & \\
\hline GENDER & $\begin{array}{c}0.026 \\
(0.098)\end{array}$ & & $\begin{array}{c}0.145 \\
(0.101)\end{array}$ & & $\begin{array}{c}0.046 \\
(0.102)\end{array}$ & \\
\hline ACADEMIC & $\begin{array}{c}0.102 \\
(0.078)\end{array}$ & & $\begin{array}{c}0.024 \\
(0.080)\end{array}$ & & $\begin{array}{c}0.013 \\
(0.081)\end{array}$ & \\
\hline GOVT & $\begin{array}{l}-0.352 \\
(0.157)\end{array}$ & $* *$ & $\begin{array}{l}-0.464 \\
(0.162)\end{array}$ & $* * *$ & $\begin{array}{l}-0.412 \\
(0.163)\end{array}$ & ** \\
\hline INDUSTRY & $\begin{array}{c}0.018 \\
(0.080)\end{array}$ & & $\begin{array}{l}-0.208 \\
(0.083)\end{array}$ & $* *$ & $\begin{array}{l}-0.116 \\
(0.084)\end{array}$ & \\
\hline BOG & $\begin{array}{l}-0.052 \\
(0.078)\end{array}$ & & $\begin{array}{c}0.046 \\
(0.079)\end{array}$ & & $\begin{array}{c}0.005 \\
(0.080)\end{array}$ & \\
\hline FOMC_APPT & $\begin{array}{l}-0.008 \\
(0.010)\end{array}$ & & $\begin{array}{l}-0.006 \\
(0.009)\end{array}$ & & $\begin{array}{l}-0.006 \\
(0.010)\end{array}$ & \\
\hline FED_JOIN & $\begin{array}{c}0.008 \\
(0.003)\end{array}$ & $* *$ & $\begin{array}{c}0.002 \\
(0.003)\end{array}$ & & $\begin{array}{c}0.003 \\
(0.003)\end{array}$ & \\
\hline CHAIR_TIME & $\begin{array}{l}-0.020 \\
(0.007)\end{array}$ & ${ }^{* * *}$ & $\begin{array}{l}-0.031 \\
(0.008)\end{array}$ & $* * *$ & $\begin{array}{l}-0.047 \\
(0.008)\end{array}$ & $* * *$ \\
\hline GDP & & & $\begin{array}{c}0.227 \\
(0.018)\end{array}$ & $* * *$ & $\begin{array}{c}0.087 \\
(0.027)\end{array}$ & *** \\
\hline INFLATION & & & $\begin{array}{c}0.143 \\
(0.025)\end{array}$ & $* * *$ & $\begin{array}{c}0.806 \\
(0.140)\end{array}$ & *** \\
\hline YLD_CURVE & & & $\begin{array}{l}-0.268 \\
(0.034)\end{array}$ & $* * *$ & $\begin{array}{l}-0.359 \\
(0.037)\end{array}$ & *** \\
\hline Lag(D_TAYLOR) & & & & & $\begin{array}{c}0.636 \\
(0.092)\end{array}$ & *** \\
\hline$\nu_{1}$ & $\begin{array}{l}-1.912 \\
(0.482)\end{array}$ & & $\begin{array}{l}-0.110 \\
(0.781)\end{array}$ & & $\begin{array}{l}-0.212 \\
(0.709)\end{array}$ & \\
\hline$\gamma_{2}$ & $\begin{array}{c}0.540 \\
(0.480)\end{array}$ & & $\begin{array}{c}2.671 \\
(0.784)\end{array}$ & & $\begin{array}{c}2.562 \\
(0.711)\end{array}$ & \\
\hline$\sigma_{u}^{2}$ & $\begin{array}{c}0.084 \\
(0.035)\end{array}$ & & $\begin{array}{c}0.328 \\
(0.079)\end{array}$ & & $\begin{array}{c}0.246 \\
(0.070)\end{array}$ & \\
\hline Obs. & 3248 & & 3248 & & 3027 & \\
\hline Log-likelihood & -3261 & & -3032 & & -3029 & \\
\hline LR Test $\mathrm{v}$ ologit & 14.93 & & 95.17 & & 53.27 & \\
\hline Wald Chi2 & 33.42 & & 391.44 & & 404.74 & \\
\hline
\end{tabular}

Note: This table presents the estimates for the ordered logit model specified in eq.(1). The dependent variable is the FOMC decision at time $t$ and is assumed to be a ordered choice to decrease $(-1)$, leave-unchanged $(0)$ or increase $(+1)$ the Fed Funds target rate. $\gamma_{1}$ and $\gamma_{2}$ refer to the cut-points for each decision. Cluster robust standard errors (Rogers, 1993) are reported in parantheses. Sample period: August 1979 - February 2014.

${ }^{* * *},{ }^{* *},{ }^{*}$ denote significance at the $1 \%, 5 \%$ and $10 \%$ levels respectively. 
Table 4

Panel Regression: Factors explaining policy deviations from Taylor Rule

\begin{tabular}{|c|c|c|c|c|c|c|c|c|}
\hline $\begin{array}{l}\text { Dependent Variable: Deviation } \\
\text { from Taylor Rule }\end{array}$ & (1) & & (2) & & (3) & & (4) & \\
\hline Constant & $\begin{array}{l}10.944 \\
(0.474)\end{array}$ & **** & $\begin{array}{l}11.238 \\
(0.456)\end{array}$ & *** & $\begin{array}{c}9.079 \\
(0.885)\end{array}$ & **** & $\begin{array}{l}10.649 \\
(0.380)\end{array}$ & *** \\
\hline AGE & $\begin{array}{l}-0.007 \\
(0.007)\end{array}$ & & $\begin{array}{l}-0.007 \\
(0.006)\end{array}$ & & $\begin{array}{l}-0.021 \\
(0.015)\end{array}$ & & $\begin{array}{l}-0.004 \\
(0.005)\end{array}$ & \\
\hline EDUCATION & $\begin{array}{c}0.067 \\
(0.085)\end{array}$ & & $\begin{array}{c}0.058 \\
(0.087)\end{array}$ & & $\begin{array}{c}0.223 \\
(0.216)\end{array}$ & & $\begin{array}{c}0.013 \\
(0.083)\end{array}$ & \\
\hline P_PARTY & $\begin{array}{c}0.264 \\
(0.101)\end{array}$ & $* * *$ & $\begin{array}{c}0.185 \\
(0.088)\end{array}$ & $* *$ & $\begin{array}{c}0.836 \\
(0.214)\end{array}$ & $* * *$ & $\begin{array}{c}0.169 \\
(0.076)\end{array}$ & $* *$ \\
\hline GENDER & $\begin{array}{l}-0.196 \\
(0.104)\end{array}$ & * & $\begin{array}{l}-0.169 \\
(0.088)\end{array}$ & $*$ & $\begin{array}{l}-0.236 \\
(0.222)\end{array}$ & & $\begin{array}{l}-0.096 \\
(0.073)\end{array}$ & \\
\hline ACADEMIC & $\begin{array}{c}0.021 \\
(0.106)\end{array}$ & & $\begin{array}{c}0.009 \\
(0.093)\end{array}$ & & $\begin{array}{c}0.005 \\
(0.232)\end{array}$ & & $\begin{array}{c}0.030 \\
(0.091)\end{array}$ & \\
\hline GOVT & $\begin{array}{c}0.109 \\
(0.130)\end{array}$ & & $\begin{array}{c}0.127 \\
(0.111)\end{array}$ & & $\begin{array}{c}0.482 \\
(0.302)\end{array}$ & & $\begin{array}{c}0.085 \\
(0.127)\end{array}$ & \\
\hline INDUSTRY & $\begin{array}{c}0.146 \\
(0.111)\end{array}$ & & $\begin{array}{c}0.124 \\
(0.104)\end{array}$ & & $\begin{array}{c}0.269 \\
(0.234)\end{array}$ & & $\begin{array}{c}0.121 \\
(0.103)\end{array}$ & \\
\hline BOG & $\begin{array}{l}-0.168 \\
(0.089)\end{array}$ & * & $\begin{array}{l}-0.146 \\
(0.078)\end{array}$ & * & $\begin{array}{l}-0.380 \\
(0.188)\end{array}$ & $* *$ & $\begin{array}{l}-0.075 \\
(0.031)\end{array}$ & $* *$ \\
\hline FOMC_APPT & $\begin{array}{l}-0.022 \\
(0.010)\end{array}$ & $* *$ & $\begin{array}{l}-0.022 \\
(0.009)\end{array}$ & ** & $\begin{array}{c}-0.023 \\
(0.008)\end{array}$ & $* * *$ & $\begin{array}{l}-0.020 \\
(0.009)\end{array}$ & $* *$ \\
\hline FED_JOIN & $\begin{array}{c}0.012 \\
(0.004)\end{array}$ & *** & $\begin{array}{c}0.011 \\
(0.004)\end{array}$ & $* * *$ & $\begin{array}{c}0.014 \\
(0.002)\end{array}$ & $* * *$ & $\begin{array}{c}0.010 \\
(0.004)\end{array}$ & $* *$ \\
\hline CHAIR_TIME & $\begin{array}{l}-0.146 \\
(0.017)\end{array}$ & $* * *$ & $\begin{array}{l}-0.143 \\
(0.014)\end{array}$ & $* * *$ & $\begin{array}{l}-0.104 \\
(0.020)\end{array}$ & $* * *$ & $\begin{array}{l}-0.153 \\
(0.015)\end{array}$ & $* * *$ \\
\hline GREENSPAN & $\begin{array}{l}-2.183 \\
(0.193)\end{array}$ & $* * *$ & $\begin{array}{c}-2.318 \\
(0.201)\end{array}$ & $* * *$ & $\begin{array}{l}-1.802 \\
(0.337)\end{array}$ & $* * *$ & $\begin{array}{l}-2.345 \\
(0.183)\end{array}$ & *** \\
\hline BERNANKE & $\begin{array}{l}-4.431 \\
(0.459)\end{array}$ & $* * *$ & $\begin{array}{l}-4.345 \\
(0.402)\end{array}$ & $* * *$ & $\begin{array}{l}-2.910 \\
(0.755)\end{array}$ & $* * *$ & $\begin{array}{l}-4.311 \\
(0.413)\end{array}$ & $* * *$ \\
\hline D_VCHAIR & $\begin{array}{l}-0.871 \\
(0.088)\end{array}$ & $* * *$ & $\begin{array}{c}-0.874 \\
(0.082)\end{array}$ & $* * *$ & $\begin{array}{l}-1.749 \\
(0.175)\end{array}$ & $* * *$ & $\begin{array}{l}-0.665 \\
(0.090)\end{array}$ & *** \\
\hline GDP & $\begin{array}{l}-0.233 \\
(0.026)\end{array}$ & *** & $\begin{array}{l}-0.146 \\
(0.016)\end{array}$ & $* * *$ & $\begin{array}{c}-0.097 \\
(0.031)\end{array}$ & $* * *$ & $\begin{array}{c}-0.122 \\
(0.021)\end{array}$ & *** \\
\hline INFLATION & $\begin{array}{l}-1.254 \\
(0.044)\end{array}$ & *** & $\begin{array}{l}-0.692 \\
(0.151)\end{array}$ & $* * *$ & $\begin{array}{l}-0.967 \\
(0.077)\end{array}$ & $* * *$ & $\begin{array}{c}-0.743 \\
(0.069)\end{array}$ & $* * *$ \\
\hline YLD_CURVE & $\begin{array}{l}-1.451 \\
(0.028)\end{array}$ & $* * *$ & $\begin{array}{l}-1.431 \\
(0.028)\end{array}$ & $* * *$ & $\begin{array}{l}-1.550 \\
(0.046)\end{array}$ & $* * *$ & $\begin{array}{l}-1.285 \\
(0.029)\end{array}$ & $* * *$ \\
\hline Lag(D_TAYLOR) & & & $\begin{array}{c}-0.378 \\
(0.111)\end{array}$ & $* * *$ & & & $\begin{array}{l}-1.249 \\
(0.041)\end{array}$ & $* * *$ \\
\hline$\sigma_{\mathrm{u}}$ & 0.364 & & 0.267 & & 0.601 & & 0.315 & \\
\hline$\sigma_{\mathrm{e}}$ & 1.016 & & 0.984 & & 1.807 & & 1.076 & \\
\hline$\rho$ & 0.113 & & 0.069 & & 0.100 & & 0.079 & \\
\hline $\mathrm{R}^{2}$ & 0.819 & & 0.830 & & 0.594 & & 0.865 & \\
\hline within & 0.682 & & 0.694 & & 0.435 & & 0.793 & \\
\hline between & 0.942 & & 0.951 & & 0.792 & & 0.954 & \\
\hline Obs & 3248 & & 3027 & & 3248 & & 3027 & \\
\hline Wald & 1261 & & 1912 & & 3657 & & 1438 & \\
\hline
\end{tabular}

Note: This table presents the estimates for the ordinary least squares model specified in eq.(2). The dependent variable is the deviation of the Fed Funds Target from the benchmark Taylor rule (calculated by subtracting the nominal benchmark rate from the Fed Funds Target rate in place following the FOMC decision) at time $t$. Columns (1) and (2) use a Taylor Rule calculated on the basis of current period (GDP) growth and (GDP deflator) inflation, while columns (3) and (4) use forecasts for growth and inflation obtained from the OECD. Cluster robust standard errors (Rogers, 1993) are reported in parantheses. Sample period: August 1979 - February 2014.

${ }^{* * *},{ }^{* *},{ }^{*}$ denote significance at the $1 \%, 5 \%$ and $10 \%$ levels respectively. 
Table 5

Dissent from FOMC Vote

\begin{tabular}{|c|c|c|c|c|c|c|c|c|c|c|c|}
\hline Panel A & \multicolumn{4}{|c|}{ Dissent from vote outcome } & Panel B & \multicolumn{2}{|l|}{$\begin{array}{l}\text { Tighter } \\
\text { (3) }\end{array}$} & $\begin{array}{c}\text { Easier } \\
(4)\end{array}$ & \multicolumn{3}{|c|}{$\begin{array}{c}\text { Language } \\
\text { (5) }\end{array}$} \\
\hline \multirow[t]{2}{*}{ Constant } & -25.00 & & -23.57 & & & -6.769 & ** & -4.601 & * & -9.368 & * \\
\hline & $(38.24)$ & & $(27.64)$ & & & $(2.904)$ & & $(2.428)$ & & $(4.583)$ & \\
\hline \multirow[t]{2}{*}{ AGE } & -0.014 & & -0.009 & & & -0.066 & & -0.047 & & -0.025 & \\
\hline & $(0.039)$ & & $(0.033)$ & & & $(0.049)$ & & $(0.041)$ & & $(0.074)$ & \\
\hline \multirow[t]{2}{*}{ EDUCATION } & -0.245 & & -0.057 & & & 0.038 & & -0.175 & & -0.498 & \\
\hline & $(0.449)$ & & $(0.383)$ & & & $(0.545)$ & & $(0.518)$ & & $(0.849)$ & \\
\hline \multirow[t]{2}{*}{ P_PARTY } & 0.631 & & 0.500 & & & 0.281 & & 0.955 & & 0.557 & \\
\hline & $(0.502)$ & & $(0.431)$ & & & $(0.632)$ & & $(0.572)$ & & $(1.019)$ & \\
\hline \multirow[t]{2}{*}{ GENDER } & 0.024 & & -0.010 & & & -1.885 & & 0.650 & & -0.272 & \\
\hline & $(0.698)$ & & $(0.592)$ & & & $(1.128)$ & & $(0.668)$ & & $(1.585)$ & \\
\hline \multirow{2}{*}{ ACADEMIC } & 1.249 & $* *$ & 1.011 & $* *$ & & 0.637 & & 1.039 & $*$ & 0.438 & \\
\hline & $(0.568)$ & & $(0.478)$ & & & $(0.685)$ & & $(0.626)$ & & (1.029) & \\
\hline \multirow[t]{2}{*}{ GOVT } & 1.97 & & 1.83 & & & -0.265 & & 0.723 & $*$ & 0.245 & \\
\hline & $(3.824)$ & & $(2.764)$ & & & $(0.168)$ & & $(0.380)$ & & $(0.185)$ & \\
\hline \multirow[t]{2}{*}{ INDUSTRY } & 0.930 & * & 0.715 & & & 1.046 & & -0.143 & & -0.388 & \\
\hline & $(0.547)$ & & $(0.468)$ & & & $(0.729)$ & & $(0.554)$ & & $(1.086)$ & \\
\hline \multirow[t]{2}{*}{ BOG } & 0.804 & & 0.853 & * & & -1.720 & $* *$ & -0.293 & & 2.004 & $*$ \\
\hline & $(0.537)$ & & $(0.451)$ & & & $(0.686)$ & & $(0.550)$ & & $(1.180)$ & \\
\hline \multirow[t]{2}{*}{ FOMC_APPT } & -0.006 & & -0.007 & & & -0.100 & & -0.023 & & 0.319 & $* *$ \\
\hline & $(0.047)$ & & $(0.042)$ & & & $(0.057)$ & & $(0.064)$ & & $(0.138)$ & \\
\hline \multirow[t]{2}{*}{ FED_JOIN } & 0.051 & $* *$ & 0.039 & $*$ & & 0.052 & $*$ & 0.013 & & -0.116 & \\
\hline & $(0.024)$ & & $(0.020)$ & & & $(0.030)$ & & $(0.024)$ & & $(0.082)$ & \\
\hline \multirow[t]{2}{*}{ CHAIR_TIME } & -0.080 & $* * *$ & -0.064 & $* *$ & & -0.086 & $* *$ & -0.006 & & -0.070 & $* * *$ \\
\hline & $(0.026)$ & & $(0.027)$ & & & $(0.034)$ & & $(0.046)$ & & $(0.017)$ & \\
\hline \multirow[t]{2}{*}{ GDP } & 0.060 & & 0.072 & & & 0.022 & & 0.217 & $* * *$ & 0.173 & \\
\hline & $(0.042)$ & & $(0.045)$ & & & $(0.057)$ & & $(0.078)$ & & $(0.133)$ & \\
\hline \multirow[t]{2}{*}{ INFLATION } & 0.127 & $*$ & 0.093 & & & 0.015 & & 0.227 & $*$ & 0.193 & \\
\hline & $(0.073)$ & & $(0.075)$ & & & $(0.097)$ & & $(0.124)$ & & $(0.284)$ & \\
\hline \multirow[t]{2}{*}{ YLD_CURVE } & 0.110 & & 0.066 & & & 0.069 & & -0.036 & & 1.106 & $* * *$ \\
\hline & $(0.084)$ & & $(0.089)$ & & & $(0.112)$ & & $(0.151)$ & & $(0.319)$ & \\
\hline Lag(Dependent) & & & $\begin{array}{c}1.410 \\
(0.196)\end{array}$ & *** & & $\begin{array}{c}1.663 \\
(0.231)\end{array}$ & $* * *$ & $\begin{array}{c}0.599 \\
(0.361)\end{array}$ & * & $\begin{array}{c}2.615 \\
(0.575)\end{array}$ & $* * *$ \\
\hline $\ln \left(\sigma_{v}^{2}\right)$ & 1.007 & & 0.554 & & & 1.271 & & 0.455 & & 1.358 & \\
\hline & $(0.275)$ & & $(0.324)$ & & & $(0.353)$ & & $(0.205)$ & & $(0.370)$ & \\
\hline$\sigma_{v}$ & 1.654 & & 1.319 & & & 1.884 & & 1.258 & & 1.972 & \\
\hline & $(0.227)$ & & $(0.214)$ & & & $(0.334)$ & & $(0.316)$ & & $(0.720)$ & \\
\hline$\rho$ & 0.454 & & 0.346 & & & 0.520 & & 0.324 & & 0.542 & \\
\hline & $(0.068)$ & & $(0.073)$ & & & $(0.088)$ & & $(0.110)$ & & $(0.181)$ & \\
\hline Likelihood-ratio & 172.52 & & 65.69 & & & 89.14 & & 18.58 & & 14.58 & \\
\hline Log likelihood & -665.66 & & -598.46 & & & -400.19 & & -246.88 & & -95.42 & \\
\hline Wald $\left(\chi_{2,14}\right)$ & 29.35 & & 86.15 & & & 85.93 & & 22.42 & & 50.60 & \\
\hline Obs. & 3248 & & 3027 & & & 3027 & & 3027 & & 3027 & \\
\hline
\end{tabular}

Note: This table presents the estimates for the logit model specified in eq.(3). The dependent variable is a choice variable relating to the decision made by individual FOMC member $k$ at meeting $t$. Panel A relates to the choice to dissent. In columns (1) and (2) the dependent variable is the choice to dissent (1) or not (0). Panel B relates to the reasons why a FOMC member would dissent from the committee decision. In column (3) the choice is dissent in favour of tighter monetary policy than decided by the FOMC as whole (1) or not. In column (4) the choice is dissent in favour of easier monetary policy (1) or not (0). Column (5) reflects a choice between dissent on the grounds of language used (1) or not (0). Cluster robust standard errors (Rogers, 1993) are reported in parantheses. Sample period: August 1979 - February 2014.

${ }^{* * *},{ }^{* *},{ }^{*}$ denote significance at the $1 \%, 5 \%$ and $10 \%$ levels respectively. 
Table 6

Ordered Logit: Factors influencing the FOMC Decision for Disaggregated Sampl $\epsilon$

\begin{tabular}{|c|c|c|c|c|c|c|}
\hline $\begin{array}{l}\text { Dependent Variable: FOMC } \\
\text { decision }\end{array}$ & $\begin{array}{c}\text { Great } \\
\text { Moderation }\end{array}$ & & $\begin{array}{c}\text { Great } \\
\text { Recession }\end{array}$ & & ZIRP & \\
\hline$\overline{\mathrm{AGE}}$ & $\begin{array}{l}-0.001 \\
(0.016)\end{array}$ & & $\begin{array}{c}0.002 \\
(0.006)\end{array}$ & & $\begin{array}{l}-0.002 \\
(0.001)\end{array}$ & \\
\hline EDUCATION & $\begin{array}{l}-0.082 \\
(0.202)\end{array}$ & & $\begin{array}{c}0.000 \\
(0.093)\end{array}$ & & $\begin{array}{c}0.022 \\
(0.022)\end{array}$ & \\
\hline P_PARTY & $\begin{array}{c}0.668 \\
(0.221)\end{array}$ & $* * *$ & $\begin{array}{l}-0.021 \\
(0.072)\end{array}$ & & $\begin{array}{l}-0.005 \\
(0.173)\end{array}$ & \\
\hline GENDER & $\begin{array}{l}-0.091 \\
(0.306)\end{array}$ & & $\begin{array}{c}0.035 \\
(0.083)\end{array}$ & & $\begin{array}{c}0.005 \\
(0.016)\end{array}$ & \\
\hline ACADEMIC & $\begin{array}{c}0.090 \\
(0.252)\end{array}$ & & $\begin{array}{c}0.055 \\
(0.080)\end{array}$ & & $\begin{array}{l}-0.205 \\
(0.130)\end{array}$ & \\
\hline GOVT & $\begin{array}{l}-1.091 \\
(0.449)\end{array}$ & $* *$ & $\begin{array}{l}-0.357 \\
(0.178)\end{array}$ & $* *$ & $\begin{array}{l}-0.431 \\
(0.119)\end{array}$ & $* * *$ \\
\hline INDUSTRY & $\begin{array}{l}-0.526 \\
(0.239)\end{array}$ & $* *$ & $\begin{array}{c}0.051 \\
(0.075)\end{array}$ & & $\begin{array}{c}0.062 \\
(0.078)\end{array}$ & \\
\hline BOG & $\begin{array}{l}-0.123 \\
(0.232)\end{array}$ & & $\begin{array}{c}0.020 \\
(0.084)\end{array}$ & & $\begin{array}{c}0.031 \\
(0.023)\end{array}$ & \\
\hline FOMC_APPT & $\begin{array}{c}0.056 \\
(0.022)\end{array}$ & $* *$ & $\begin{array}{l}-0.004 \\
(0.007)\end{array}$ & & $\begin{array}{l}-0.004 \\
(0.002)\end{array}$ & $* *$ \\
\hline FED_JOIN & $\begin{array}{l}-0.006 \\
(0.010)\end{array}$ & & $\begin{array}{c}0.002 \\
(0.004)\end{array}$ & & $\begin{array}{c}0.003 \\
(0.001)\end{array}$ & $* *$ \\
\hline CHAIR_TIME & $\begin{array}{c}0.052 \\
(0.013)\end{array}$ & $* * *$ & $\begin{array}{c}0.076 \\
(0.010)\end{array}$ & $* * *$ & $\begin{array}{c}0.040 \\
(0.007)\end{array}$ & $* * *$ \\
\hline GDP & $\begin{array}{c}0.675 \\
(0.066)\end{array}$ & $* * *$ & $\begin{array}{l}-0.048 \\
(0.014)\end{array}$ & $* * *$ & $\begin{array}{l}-0.016 \\
(0.011)\end{array}$ & \\
\hline INFLATION & $\begin{array}{c}1.416 \\
(0.394)\end{array}$ & $* * *$ & $\begin{array}{l}-0.416 \\
(0.060)\end{array}$ & $* * *$ & $\begin{array}{l}-0.192 \\
(0.039)\end{array}$ & $* * *$ \\
\hline YLD_CURVE & $\begin{array}{l}-0.299 \\
(0.051)\end{array}$ & $* * *$ & $\begin{array}{c}0.062 \\
(0.012)\end{array}$ & $* * *$ & $\begin{array}{c}0.055 \\
(0.014)\end{array}$ & $* * *$ \\
\hline Lag(D_TAYLOR) & $\begin{array}{c}-0.382 \\
(0.245)\end{array}$ & & $\begin{array}{c}0.163 \\
(0.032)\end{array}$ & $* * *$ & $\begin{array}{c}0.076 \\
(0.022)\end{array}$ & $* * *$ \\
\hline$\gamma_{1}$ & $\begin{array}{l}-1.639 \\
(1.075)\end{array}$ & & $\begin{array}{l}-1.107 \\
(1.289)\end{array}$ & & $\begin{array}{c}1.107 \\
(1.289)\end{array}$ & \\
\hline$\gamma_{2}$ & $\begin{array}{c}4.459 \\
(1.082)\end{array}$ & & $\begin{array}{c}3.889 \\
(1.293)\end{array}$ & & $\begin{array}{c}3.889 \\
(1.293)\end{array}$ & \\
\hline$\sigma_{\mathrm{u}}^{2}$ & $\begin{array}{c}0.503 \\
(0.159)\end{array}$ & & $\begin{array}{c}0.296 \\
(0.072)\end{array}$ & & $\begin{array}{c}0.296 \\
(0.072)\end{array}$ & \\
\hline Obs. & 2337 & & 572 & & 442 & \\
\hline Log-likelihood & -2119 & & -3028 & & -3028 & \\
\hline LR Test v ologit & 57.75 & & 85.83 & & 85.83 & \\
\hline Wald Chi2 & 473.49 & & 398.38 & & 398.38 & \\
\hline
\end{tabular}

Note: This table presents the estimates for the ordered logit model specified in eq.(1). Thedependent variable is the FOMC decision at time $t$ and is assumed to be a ordered choice to decrease $(-1)$, leave-unchanged $(0)$ or increase $(+1)$ the Fed Funds target rate. The sample is disaggregated into periods representing the Great Moderation, the Great Recession, and the period of zero interest rate policy (ZIRP). Following the Federal Reserve, the Great Moderation is defined as the period January 1982 - July 2007, the Great Recession as August 2007 - January 2013, and ZIRP is defined as December 2008 (when the Fed Funds rate reached the zero-bound) until the end of the sample period. $\gamma_{1}$ and $\gamma_{2}$ refer to the cut-points for each decision. Cluster robust standard errors (Rogers, 1993) are reported in parantheses. Sample period: January 1982 - February 2014.

${ }^{* * *},{ }^{* *},{ }^{*}$ denote significance at the $1 \%, 5 \%$ and $10 \%$ levels respectively 
Table 7

Panel Regression: Factors explaining policy deviations from Taylor Rule for disaggregated sample

\begin{tabular}{|c|c|c|c|c|c|c|c|c|c|c|c|c|}
\hline \multirow{3}{*}{$\begin{array}{l}\text { Dependent Variable: } \\
\text { Deviation from Taylor Rule }\end{array}$} & \multicolumn{6}{|c|}{ Current-Period Rule } & \multicolumn{6}{|c|}{ Forward-Looking Rule } \\
\hline & Great & & Great & & ZIRP & & Great & & Great & & ZIRP & \\
\hline & Moderation & & Recession & & & & & & Recession & & & \\
\hline Constant & $\begin{array}{l}9.184 \\
(0.467)\end{array}$ & **** & $\begin{array}{l}-10.528 \\
(0.722)\end{array}$ & *** & $\begin{array}{l}-0.806 \\
(0.072)\end{array}$ & ${ }^{* * * *}$ & $\begin{array}{c}9.635 \\
(0.401)\end{array}$ & *** & $\begin{array}{c}-16.888 \\
(0.628)\end{array}$ & *** & $\begin{array}{l}-4.356 \\
(0.627)\end{array}$ & ${ }^{* * *}$ \\
\hline AGE & $\begin{array}{l}-0.002 \\
(0.004)\end{array}$ & & $\begin{array}{l}-0.005 \\
(0.007)\end{array}$ & & $\begin{array}{l}-0.004 \\
(0.005)\end{array}$ & & $\begin{array}{l}-0.002 \\
(0.003)\end{array}$ & & $\begin{array}{l}-0.009 \\
(0.004)\end{array}$ & ${ }^{* *}$ & $\begin{array}{l}-0.003 \\
(0.002)\end{array}$ & \\
\hline EDUCATION & $\begin{array}{c}0.062 \\
(0.072)\end{array}$ & & $\begin{array}{c}0.075 \\
(0.154)\end{array}$ & & $\begin{array}{c}0.011 \\
(0.006)\end{array}$ & * & $\begin{array}{l}-0.025 \\
(0.059)\end{array}$ & & $\begin{array}{c}0.060 \\
(0.079)\end{array}$ & & $\begin{array}{l}0.015 \\
(0.035)\end{array}$ & \\
\hline P_PARTY & $\begin{array}{c}0.171 \\
(0.065)\end{array}$ & ${ }^{* * *}$ & $\begin{array}{l}-0.112 \\
(0.108)\end{array}$ & & $\begin{array}{l}-0.003 \\
(0.005)\end{array}$ & & $\begin{array}{c}0.205 \\
(0.058)\end{array}$ & $* * *$ & $\begin{array}{l}-0.070 \\
(0.047)\end{array}$ & & $\begin{array}{l}-0.005 \\
(0.020)\end{array}$ & \\
\hline GENDER & $\begin{array}{l}-0.048 \\
(0.071)\end{array}$ & & $\begin{array}{l}-0.106 \\
(0.088)\end{array}$ & & $\begin{array}{l}-0.011 \\
(0.006)\end{array}$ & $*$ & $\begin{array}{l}-0.033 \\
(0.052)\end{array}$ & & $\begin{array}{l}-0.032 \\
(0.047)\end{array}$ & & $\begin{array}{l}-0.031 \\
(0.016)\end{array}$ & $*$ \\
\hline ACADEMIC & $\begin{array}{c}0.052 \\
(0.074)\end{array}$ & & $\begin{array}{l}-0.048 \\
(0.149)\end{array}$ & & $\begin{array}{l}-0.023 \\
(0.006)\end{array}$ & $* * *$ & $\begin{array}{c}0.064 \\
(0.054)\end{array}$ & & $\begin{array}{l}-0.030 \\
(0.093)\end{array}$ & & $\begin{array}{l}-0.012 \\
(0.054)\end{array}$ & $* * *$ \\
\hline GOVT & $\begin{array}{c}0.216 \\
(0.173)\end{array}$ & & $\begin{array}{l}-0.075 \\
(0.224)\end{array}$ & & $\begin{array}{l}-0.007 \\
(0.011)\end{array}$ & & $\begin{array}{l}-0.023 \\
(0.133)\end{array}$ & & $\begin{array}{l}-0.292 \\
(0.130)\end{array}$ & $* *$ & $\begin{array}{l}-0.188 \\
(0.078)\end{array}$ & $* * *$ \\
\hline INDUSTRY & $\begin{array}{c}0.102 \\
(0.060)\end{array}$ & $*$ & $\begin{array}{l}-0.090 \\
(0.133)\end{array}$ & & $\begin{array}{l}-0.015 \\
(0.008)\end{array}$ & $*$ & $\begin{array}{c}-0.008 \\
(0.051)\end{array}$ & & $\begin{array}{c}-0.052 \\
(0.071)\end{array}$ & & $\begin{array}{l}-0.017 \\
(0.042)\end{array}$ & \\
\hline BOG & $\begin{array}{c}-0.001 \\
(0.057)\end{array}$ & & $\begin{array}{l}-0.033 \\
(0.116)\end{array}$ & & $\begin{array}{l}-0.009 \\
(0.006)\end{array}$ & & $\begin{array}{l}-0.027 \\
(0.049)\end{array}$ & & $\begin{array}{l}-0.059 \\
(0.068)\end{array}$ & & $\begin{array}{l}-0.001 \\
(0.036)\end{array}$ & \\
\hline FOMC_APPT & $\begin{array}{c}-0.016 \\
(0.008)\end{array}$ & $* *$ & $\begin{array}{l}-0.008 \\
(0.011)\end{array}$ & & $\begin{array}{l}-0.001 \\
(0.001)\end{array}$ & & $\begin{array}{l}-0.011 \\
(0.007)\end{array}$ & & $\begin{array}{c}-0.004 \\
(0.006)\end{array}$ & & $\begin{array}{l}-0.001 \\
(0.002)\end{array}$ & \\
\hline FED_JOIN & $\begin{array}{c}0.007 \\
(0.003)\end{array}$ & *** & $\begin{array}{l}-0.004 \\
(0.008)\end{array}$ & & $\begin{array}{c}0.009 \\
(0.004)\end{array}$ & * & $\begin{array}{c}0.005 \\
(0.002)\end{array}$ & ${ }^{* *}$ & $\begin{array}{c}0.006 \\
(0.005)\end{array}$ & & $\begin{array}{c}0.002 \\
(0.003)\end{array}$ & \\
\hline CHAIR_TIME & $\begin{array}{l}-0.143 \\
(0.009)\end{array}$ & ${ }^{* * *}$ & $\begin{array}{l}-0.249 \\
(0.060)\end{array}$ & $* * *$ & $\begin{array}{l}-0.178 \\
(0.003)\end{array}$ & $* * *$ & $\begin{array}{c}-0.130 \\
(0.006)\end{array}$ & $* * *$ & $\begin{array}{l}-0.109 \\
(0.029)\end{array}$ & $* * *$ & $\begin{array}{l}-0.041 \\
(0.013)\end{array}$ & $* * *$ \\
\hline GREENSPAN & $\begin{array}{l}-1.924 \\
(0.127)\end{array}$ & *** & & & & & $\begin{array}{l}-1.934 \\
(0.120)\end{array}$ & *** & & & & \\
\hline BERNANKE & $\begin{array}{l}-4.396 \\
(0.266)\end{array}$ & *** & & & & & $\begin{array}{l}-4.105 \\
(0.203)\end{array}$ & $* * *$ & & & & \\
\hline D_VCHAIR & $\begin{array}{l}-0.816 \\
(0.086)\end{array}$ & *** & $\begin{array}{l}-1.664 \\
(0.272)\end{array}$ & $* * *$ & $\begin{array}{l}-0.167 \\
(0.011)\end{array}$ & $* * *$ & $\begin{array}{l}-0.931 \\
(0.042)\end{array}$ & *** & $\begin{array}{l}-3.914 \\
(0.202)\end{array}$ & $* * *$ & $\begin{array}{l}-1.167 \\
(0.171)\end{array}$ & $* * *$ \\
\hline GDP & $\begin{array}{l}-0.123 \\
(0.016)\end{array}$ & ${ }^{* * *}$ & $\begin{array}{l}-0.129 \\
(0.031)\end{array}$ & $* * *$ & $\begin{array}{l}-0.481 \\
(0.002)\end{array}$ & $* * *$ & $\begin{array}{l}-0.189 \\
(0.024)\end{array}$ & $* * *$ & $\begin{array}{l}-0.028 \\
(0.019)\end{array}$ & & $\begin{array}{l}-0.021 \\
(0.013)\end{array}$ & $*$ \\
\hline INFLATION & $\begin{array}{l}-0.766 \\
(0.070)\end{array}$ & *** & $\begin{array}{l}-1.226 \\
(0.123)\end{array}$ & $* * *$ & $\begin{array}{l}-1.677 \\
(0.019)\end{array}$ & $* * *$ & $\begin{array}{c}1.085 \\
(0.093)\end{array}$ & $* * *$ & $\begin{array}{l}-0.733 \\
(0.058)\end{array}$ & $* * *$ & $\begin{array}{l}-0.277 \\
(0.038)\end{array}$ & $* * *$ \\
\hline YLD_C & $\begin{array}{l}-1.488 \\
(0.028)\end{array}$ & ${ }^{* * *}$ & $\begin{array}{l}-0.863 \\
(0.128)\end{array}$ & ${ }^{* * *}$ & $\begin{array}{c}-0.144 \\
(0.005)\end{array}$ & $* * *$ & $\begin{array}{l}-1.388 \\
(0.027)\end{array}$ & *** & $\begin{array}{l}-0.667 \\
(0.049)\end{array}$ & $* * *$ & $\begin{array}{l}-0.184 \\
(0.028)\end{array}$ & $* * *$ \\
\hline Lag(D_TAYLOR) & $\begin{array}{l}-0.085 \\
(0.055)\end{array}$ & & $\begin{array}{l}-0.466 \\
(0.046)\end{array}$ & $* * *$ & $\begin{array}{l}-0.077 \\
(0.007)\end{array}$ & ${ }^{* * *}$ & $\begin{array}{l}-1.253 \\
(0.038)\end{array}$ & *** & $\begin{array}{c}-0.332 \\
(0.045)\end{array}$ & ${ }^{* * *}$ & $\begin{array}{l}-0.689 \\
(0.055)\end{array}$ & *** \\
\hline$\sigma_{\mathrm{u}}$ & 0.184 & & 0.178 & & 0.164 & & 0.222 & & 0.245 & & 0.216 & \\
\hline$\sigma_{\mathrm{e}}$ & 0.612 & & 0.652 & & 0.636 & & 0.671 & & 0.674 & & 0.628 & \\
\hline$\rho$ & 0.083 & & 0.076 & & 0.068 & & 0.098 & & 0.103 & & 0.089 & \\
\hline $\mathrm{R}^{2}$ & 0.903 & & 0.874 & & 0.862 & & 0.919 & & 0.957 & & 0.897 & \\
\hline within & 0.850 & & 0.841 & & 0.838 & & 0.882 & & 0.926 & & 0.872 & \\
\hline between & 0.970 & & 0.921 & & 0.918 & & 0.967 & & 0.991 & & 0.996 & \\
\hline Obs & 2190 & & 531 & & 411 & & 2190 & & 531 & & 411 & \\
\hline Wald & 1975 & & 1598 & & 1486 & & 2725 & & 1638 & & 1810 & \\
\hline
\end{tabular}

Note: This table presents the estimates for an ordinary least squares model specified in eq.(2). The sample is disaggregated into periods representing the Great Moderation, the Great Recession, and the period of zero interest rate policy (ZIRP). Following the Federal Reserve, the Great Moderation is defined as the period January 1982 - July 2007, the Great Recession as August 2007 - January 2013, and ZIRP is defined as December 2008 (when the Fed Funds rate reached the zero-bound) until the end of the sample period. The dependent variable is the deviation of the Fed Funds Target from the benchmark Taylor rule (calculated by subtracting the nominal benchmark rate from the Fed Funds Target rate in place following the FOMC decision) at time $t$. The first two columns use a Taylor Rule calculated on the basis of current period (GDP) growth and (GDP deflator) inflation, while the latter two columns use forecasts for growth and inflation obtained from the OECD. Cluster robust standard errors (Rogers, 1993) are reported in parantheses. Sample period: January 1982 - February 2014. ***, ${ }^{* *},{ }^{*}$ denote significance at the $1 \%, 5 \%$ and $10 \%$ levels respectively. 
Table 8

Dissent from FOMC Vote for disaggregated sample

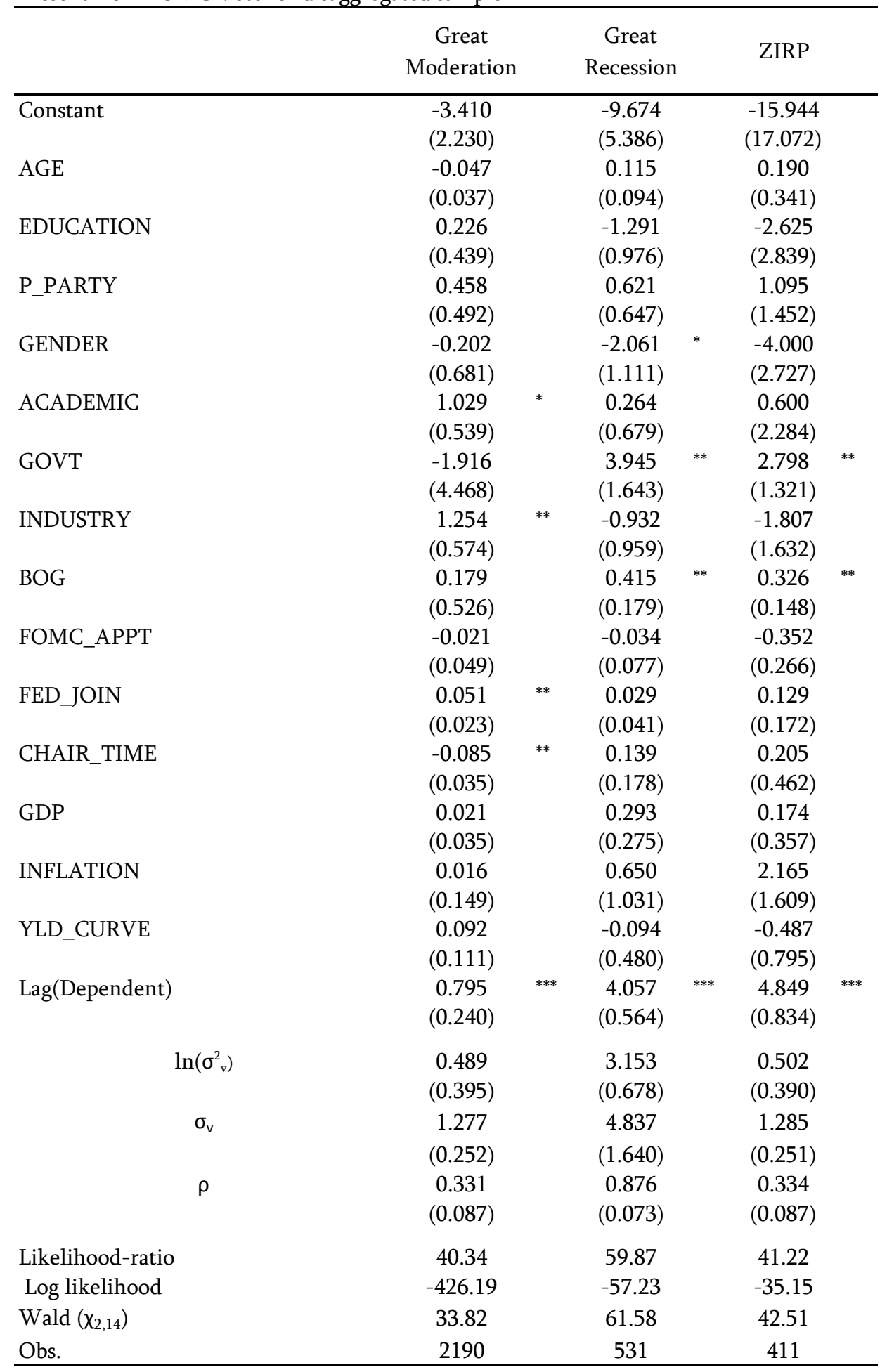

Note: This table presents the estimates for the logit model specified in eq.(3). The sample is disaggregated into periods representing the Great Moderation, the Great Recession, and the period of zero interest rate policy (ZIRP). Following the Federal Reserve, the Great Moderation is defined as the period January 1982 - July 2007, the Great Recession as August 2007 - January 2013, and ZIRP is defined as December 2008 (when the Fed Funds rate reached the zero-bound) until the end of the sample period. The dependent variable is a choice variable relating to the decision made by individual FOMC member $k$ at meeting $t$; the choice to dissent (1) or not (0). Cluster robust standard errors (Rogers, 1993) are reported in parantheses. Sample period: January 1982 - February 2014.

${ }^{* * *},{ }^{* *},{ }^{*}$ denote significance at the $1 \%, 5 \%$ and $10 \%$ levels respectively. 
Appendix 1

Robustness Test for Education and Career: Factors influencing the FOMC Decision

\begin{tabular}{|c|c|c|c|c|c|c|c|c|}
\hline $\begin{array}{l}\text { Dependent Variable: FOMC } \\
\text { decision }\end{array}$ & \multicolumn{2}{|l|}{ (1) } & $(2)$ & \multicolumn{3}{|c|}{ (3) } & $(4)$ & \\
\hline \multirow[t]{2}{*}{$\overline{\mathrm{AGE}}$} & -0.004 & & 0.006 & & 0.002 & & 0.002 & \\
\hline & $(0.008)$ & & $(0.012)$ & & $(0.011)$ & & $(0.011)$ & \\
\hline \multirow[t]{2}{*}{ MASTERS } & -0.417 & $*$ & 0.109 & & 0.017 & & 0.019 & \\
\hline & $(0.209)$ & & $(0.316)$ & & $(0.290)$ & & $(0.289)$ & \\
\hline \multirow[t]{2}{*}{ DOCTORATE } & -0.583 & *** & -0.105 & & -0.044 & & -0.045 & \\
\hline & $(0.210)$ & & $(0.317)$ & & $(0.289)$ & & $(0.290)$ & \\
\hline \multirow[t]{2}{*}{ P_PARTY } & -0.397 & $* * *$ & -0.021 & & -0.060 & & -0.009 & \\
\hline & $(0.104)$ & & $(0.160)$ & & $(0.145)$ & & $(0.186)$ & \\
\hline \multirow[t]{2}{*}{ GENDER } & 0.003 & & 0.065 & & 0.018 & & 0.018 & \\
\hline & $(0.135)$ & & $(0.213)$ & & $(0.192)$ & & $(0.192)$ & \\
\hline \multirow[t]{2}{*}{ ACADEMIC } & 0.965 & ** & 1.827 & $* *$ & 1.696 & $* *$ & 1.688 & *** \\
\hline & $(0.484)$ & & $(0.740)$ & & $(0.674)$ & & $(0.658)$ & \\
\hline \multirow[t]{2}{*}{ GOVT } & 0.243 & & 0.821 & & 0.695 & & 0.678 & \\
\hline & $(0.768)$ & & $(1.093)$ & & $(1.006)$ & & $(0.986)$ & \\
\hline \multirow[t]{2}{*}{ INDUSTRY } & 0.364 & & 0.608 & & 0.459 & & 0.448 & \\
\hline & $(0.707)$ & & $(0.997)$ & & $(0.919)$ & & $(0.914)$ & \\
\hline \multirow[t]{2}{*}{ ACADEMIC ${ }^{*}$ GOVT } & -0.742 & $* *$ & -1.609 & $* *$ & -1.547 & $* *$ & -1.539 & $* *$ \\
\hline & $(0.367)$ & & $(0.616)$ & & $(0.650)$ & & $(0.631)$ & \\
\hline \multirow[t]{2}{*}{ ACADEMIC*INDUSTRY } & -0.304 & & -0.444 & & -0.355 & & -0.354 & \\
\hline & $(0.219)$ & & $(0.339)$ & & $(0.309)$ & & $(0.309)$ & \\
\hline \multirow[t]{2}{*}{ GOVT*INDUSTRY } & -0.148 & & -0.626 & & -0.459 & & -0.446 & \\
\hline & $(0.686)$ & & $(0.965)$ & & $(0.891)$ & & $(0.889)$ & \\
\hline \multirow[t]{2}{*}{ BOG } & 0.019 & & 0.068 & & 0.037 & & 0.032 & \\
\hline & $(0.114)$ & & $(0.176)$ & & $(0.159)$ & & $(0.192)$ & \\
\hline \multirow[t]{2}{*}{ FOMC_APPT } & -0.009 & & 0.169 & & 0.012 & & 0.012 & \\
\hline & $(0.012)$ & & $(0.016)$ & & $(0.015)$ & & $(0.015)$ & \\
\hline \multirow[t]{2}{*}{ FED_JOIN } & 0.006 & *** & 0.003 & & 0.002 & & 0.002 & \\
\hline & $(0.002)$ & & $(0.008)$ & & $(0.007)$ & & $(0.007)$ & \\
\hline \multirow[t]{2}{*}{ CHAIR_TIME } & -0.028 & *** & -0.039 & $* * *$ & -0.045 & $* * *$ & 0.045 & *** \\
\hline & $(0.008)$ & & $(0.009)$ & & $(0.009)$ & & $(0.010)$ & \\
\hline GDP & & & 0.302 & $* * *$ & 0.221 & $* * *$ & 0.221 & *** \\
\hline & & & $(0.021)$ & & $(0.039)$ & & $(0.039)$ & \\
\hline INFLATION & & & 0.237 & $* * *$ & 0.225 & $* * *$ & 0.226 & *** \\
\hline & & & $(0.035)$ & & $(0.039)$ & & $(0.039)$ & \\
\hline YLD_CURVE & & & -0.314 & $* * *$ & -0.349 & $* * *$ & -0.349 & $* * *$ \\
\hline & & & $(0.038)$ & & $(0.041)$ & & $(0.041)$ & \\
\hline Lag(D_TAYLOR) & & & & & 0.295 & $* *$ & 0.295 & ** \\
\hline & & & & & $(0.122)$ & & $(0.122)$ & \\
\hline$\gamma_{1}$ & -0.974 & & -1.107 & & -0.852 & & 0.841 & \\
\hline & $(0.866)$ & & $(1.289)$ & & (1.199) & & $(1.202)$ & \\
\hline$\gamma_{2}$ & 1.477 & & 3.889 & & 3.627 & & 3.616 & \\
\hline & $(0.867)$ & & $(1.293)$ & & $(1.202)$ & & $(1.205)$ & \\
\hline$\sigma_{u}^{2}$ & 0.066 & & 0.296 & & 0.221 & & 0.221 & \\
\hline & $(0.031)$ & & $(0.072)$ & & $(0.065)$ & & $(0.065)$ & \\
\hline Obs. & 3248 & & 3248 & & 3248 & & & \\
\hline Log-likelihood & -3257 & & -3028 & & -3025 & & & \\
\hline LR Test v ologit & 9.72 & & 85.83 & & 46.38 & & & \\
\hline Wald Chi2 & 42.42 & & 398.38 & & 411.54 & & & \\
\hline
\end{tabular}

Note: This table presents the estimates for robustness testing of the ordered logit model specified in eq.(1). The dependent variable is the FOMC decision at time $t$ and is assumed to be a ordered choice to decrease $(-1)$, leave-unchanged $(0)$ or increase $(+1)$ the Fed Funds target rate. $\gamma_{1}$ and $\gamma_{2}$ refer to the cut-points for each decision. Model 4 differs from Model 3 in only one term, partisan appointments $\left(P_{-} P A R T Y\right)$ are assigned only to members of the Board of Governors, and not FOMC members who are presidents of the district Federal Reserve Banks. Cluster robust standard errors (Rogers, 1993) are reported in parantheses. Sample period: August 1979 - February 2014. ${ }^{* * *},{ }^{* *},{ }^{*}$ denote significance at the $1 \%, 5 \%$ and $10 \%$ levels respectively. 
Appendix 2

Robustness Test for alternate specifications of Chair, Education, and Career: Factors explaining policy deviations from Taylor Rule

\begin{tabular}{|c|c|c|c|c|c|c|c|c|}
\hline $\begin{array}{l}\text { Dependent Variable: } \\
\text { Deviation from Taylor Rule }\end{array}$ & (1) & & (2) & & (3) & & (4) & \\
\hline Constant & $\begin{array}{l}11.167 \\
(0.457)\end{array}$ & $* * *$ & $\begin{array}{l}11.982 \\
(0.620)\end{array}$ & $* * *$ & $\begin{array}{l}10.588 \\
(0.380)\end{array}$ & *** & $\begin{array}{l}10.830 \\
(0.628)\end{array}$ & *** \\
\hline AGE & $\begin{array}{l}-0.006 \\
(0.006)\end{array}$ & & $\begin{array}{l}-0.007 \\
(0.006)\end{array}$ & & $\begin{array}{l}-0.002 \\
(0.005)\end{array}$ & & $\begin{array}{l}-0.004 \\
(0.005)\end{array}$ & \\
\hline EDUCATION & $\begin{array}{c}0.054 \\
(0.086)\end{array}$ & & & & $\begin{array}{c}0.005 \\
(0.082)\end{array}$ & & & \\
\hline MASTERS & & & $\begin{array}{c}0.051 \\
(0.251)\end{array}$ & & & & $\begin{array}{c}0.117 \\
(0.257)\end{array}$ & \\
\hline DOCTORATE & & & $\begin{array}{c}0.087 \\
(0.244)\end{array}$ & & & & $\begin{array}{c}0.039 \\
(0.235)\end{array}$ & \\
\hline P_PARTY & $\begin{array}{c}0.183 \\
(0.087)\end{array}$ & $* *$ & $\begin{array}{c}0.208 \\
(0.088)\end{array}$ & $* *$ & $\begin{array}{c}0.203 \\
(0.079)\end{array}$ & ** & $\begin{array}{c}0.212 \\
(0.085)\end{array}$ & $* *$ \\
\hline GENDER & $\begin{array}{l}-0.165 \\
(0.084)\end{array}$ & * & $\begin{array}{l}-0.176 \\
(0.093)\end{array}$ & * & $\begin{array}{c}-0.088 \\
(0.071)\end{array}$ & & $\begin{array}{l}-0.077 \\
(0.067)\end{array}$ & \\
\hline ACADEMIC & $\begin{array}{c}0.014 \\
(0.093)\end{array}$ & & $\begin{array}{c}0.409 \\
(0.299)\end{array}$ & & $\begin{array}{c}0.037 \\
(0.091)\end{array}$ & & $\begin{array}{c}0.081 \\
(0.382)\end{array}$ & \\
\hline GOVT & $\begin{array}{c}0.105 \\
(0.110)\end{array}$ & & $\begin{array}{c}0.476 \\
(0.380)\end{array}$ & & $\begin{array}{c}0.059 \\
(0.126)\end{array}$ & & $\begin{array}{c}0.059 \\
(0.457)\end{array}$ & \\
\hline INDUSTRY & $\begin{array}{c}0.111 \\
(0.103)\end{array}$ & & $\begin{array}{l}-0.564 \\
(0.338)\end{array}$ & * & $\begin{array}{c}0.096 \\
(0.102)\end{array}$ & & $\begin{array}{c}0.020 \\
(0.408)\end{array}$ & \\
\hline ACADEMIC*GOVT & & & $\begin{array}{c}0.257 \\
(0.311)\end{array}$ & & & & $\begin{array}{c}0.129 \\
(0.382)\end{array}$ & \\
\hline ACADEMIC*INDUSTRY & & & $\begin{array}{c}0.276 \\
(0.214)\end{array}$ & & & & $\begin{array}{l}-0.028 \\
(0.223)\end{array}$ & \\
\hline GOVT*INDUSTRY & & & $\begin{array}{c}0.549 \\
(0.313)\end{array}$ & * & & & $\begin{array}{c}0.128 \\
(0.381)\end{array}$ & \\
\hline BOG & $\begin{array}{l}-0.149 \\
(0.079)\end{array}$ & $*$ & $\begin{array}{l}-0.204 \\
(0.093)\end{array}$ & $* *$ & $\begin{array}{l}-0.071 \\
(0.031)\end{array}$ & $* *$ & $\begin{array}{l}-0.065 \\
(0.034)\end{array}$ & $*$ \\
\hline FOMC_APPT & $\begin{array}{l}-0.021 \\
(0.009)\end{array}$ & $* *$ & $\begin{array}{l}-0.022 \\
(0.009)\end{array}$ & $* *$ & $\begin{array}{l}-0.019 \\
(0.009)\end{array}$ & ** & $\begin{array}{l}-0.021 \\
(0.010)\end{array}$ & $* *$ \\
\hline FED_JOIN & $\begin{array}{c}0.012 \\
(0.004)\end{array}$ & $* * *$ & $\begin{array}{c}0.012 \\
(0.004)\end{array}$ & $* * *$ & $\begin{array}{c}0.010 \\
(0.004)\end{array}$ & ** & $\begin{array}{c}0.010 \\
(0.004)\end{array}$ & ** \\
\hline CHAIR_TIME & $\begin{array}{l}-0.154 \\
(0.012)\end{array}$ & $* * *$ & $\begin{array}{l}-0.145 \\
(0.014)\end{array}$ & $* * *$ & $\begin{array}{l}-0.169 \\
(0.011)\end{array}$ & *** & $\begin{array}{l}-0.153 \\
(0.015)\end{array}$ & *** \\
\hline D_CHAIR & $\begin{array}{l}-2.288 \\
(0.194)\end{array}$ & $* * *$ & & & $\begin{array}{l}-2.317 \\
(0.175)\end{array}$ & $* * *$ & & \\
\hline GREENSPAN & & & $\begin{array}{l}-2.333 \\
(0.201)\end{array}$ & $* * *$ & & & $\begin{array}{l}-2.339 \\
(0.186)\end{array}$ & $* * *$ \\
\hline BERNANKE & & & $\begin{array}{l}-4.376 \\
(0.401)\end{array}$ & $* * *$ & & & $\begin{array}{l}-4.284 \\
(0.419)\end{array}$ & $* * *$ \\
\hline D_VCHAIR & $\begin{array}{l}-0.808 \\
(0.077)\end{array}$ & $* * *$ & $\begin{array}{l}-0.866 \\
(0.082)\end{array}$ & $* * *$ & $\begin{array}{l}-0.573 \\
(0.073)\end{array}$ & $* * *$ & $\begin{array}{l}-0.664 \\
(0.091)\end{array}$ & *** \\
\hline GDP & $\begin{array}{l}-0.151 \\
(0.016)\end{array}$ & $* * *$ & $\begin{array}{l}-0.147 \\
(0.017)\end{array}$ & $* * *$ & $\begin{array}{l}-0.122 \\
(0.022)\end{array}$ & $* * *$ & $\begin{array}{l}-0.122 \\
(0.022)\end{array}$ & $* * *$ \\
\hline INFLATION & $\begin{array}{l}-0.721 \\
(0.155)\end{array}$ & $* * *$ & $\begin{array}{l}-0.697 \\
(0.152)\end{array}$ & $* * *$ & $\begin{array}{l}-0.757 \\
(0.071)\end{array}$ & $* * *$ & $\begin{array}{l}-0.743 \\
(0.069)\end{array}$ & $* * *$ \\
\hline YLD_CURVE & $\begin{array}{l}-1.428 \\
(0.027)\end{array}$ & $* * *$ & $\begin{array}{l}-1.429 \\
(0.028)\end{array}$ & $* * *$ & $\begin{array}{l}-1.278 \\
(0.027)\end{array}$ & $* * *$ & $\begin{array}{l}-1.285 \\
(0.029)\end{array}$ & $* * *$ \\
\hline Lag(D_TAYLOR) & $\begin{array}{l}-0.355 \\
(0.115)\end{array}$ & $* * *$ & $\begin{array}{l}-0.373 \\
(0.112)\end{array}$ & $* * *$ & $\begin{array}{l}-1.256 \\
(0.041)\end{array}$ & $* * *$ & $\begin{array}{l}-1.250 \\
(0.041)\end{array}$ & $* * *$ \\
\hline$\sigma_{\mathrm{u}}$ & 0.279 & & 0.273 & & 0.312 & & 0.319 & \\
\hline$\sigma_{\mathrm{e}}$ & 0.984 & & 0.984 & & 1.076 & & 1.076 & \\
\hline$\rho$ & 0.074 & & 0.071 & & 0.078 & & 0.081 & \\
\hline $\mathrm{R}^{2}$ & 0.830 & & 0.830 & & 0.865 & & 0.865 & \\
\hline within & 0.693 & & 0.693 & & 0.793 & & 0.793 & \\
\hline between & 0.951 & & 0.952 & & 0.954 & & 0.954 & \\
\hline Obs & 3027 & & 3027 & & 3027 & & 3027 & \\
\hline Wald & 1877 & & 2469 & & 1352 & & 2061 & \\
\hline
\end{tabular}

Note: This table presents the estimates for robustness testing of the ordinary least squares model specified in eq.(2). The dependent variable is the deviation of the Fed Funds Target from the benchmark Taylor rule (calculated by subtracting the nominal benchmark rate from the Fed Funds Target rate in place following the FOMC decision) at time $t$. Columns (1) and (2) use a Taylor Rule calculated on the basis of current period (GDP) growth and (GDP deflator) inflation, while columns (3) and (4) use forecasts for growth and inflation obtained from the OECD. Cluster robust standard errors (Rogers, 1993) are reported in parantheses. Sample period: August 1979 - February 2014. ${ }^{* * *},{ }^{* *},{ }^{*}$ denote significance at the $1 \%, 5 \%$ and $10 \%$ levels respectively. 
Appendix 3

Robustness Test for Education and Career: Dissent from FOMC Vote

\begin{tabular}{|c|c|c|c|c|c|c|c|c|}
\hline Panel A & $\begin{array}{c}\text { Dissent } \\
(1) \\
\end{array}$ & & $\begin{array}{l}\text { Tighter } \\
(2)\end{array}$ & & $\begin{array}{c}\text { Easier } \\
(3)\end{array}$ & & $\begin{array}{c}\text { Language } \\
\text { (4) }\end{array}$ & \\
\hline Constant & $\begin{array}{l}-4.922 \\
(2.113)\end{array}$ & ** & $\begin{array}{l}-6.468 \\
(3.006)\end{array}$ & ** & $\begin{array}{l}-3.276 \\
(2.428)\end{array}$ & & $\begin{array}{l}-6.503 \\
(2.944)\end{array}$ & * \\
\hline AGE & $\begin{array}{l}-0.009 \\
(0.033)\end{array}$ & & $\begin{array}{l}-0.003 \\
(0.047)\end{array}$ & & $\begin{array}{l}-0.049 \\
(0.037)\end{array}$ & & $\begin{array}{l}-0.002 \\
(0.041)\end{array}$ & \\
\hline MASTERS & $\begin{array}{l}-0.425 \\
(0.827)\end{array}$ & & $\begin{array}{c}0.059 \\
(1.146)\end{array}$ & & $\begin{array}{l}-1.619 \\
(0.996)\end{array}$ & & $\begin{array}{l}-0.012 \\
(1.253)\end{array}$ & \\
\hline DOCTORATE & $\begin{array}{l}-0.293 \\
(0.843)\end{array}$ & & $\begin{array}{l}-0.126 \\
(1.174)\end{array}$ & & $\begin{array}{l}-1.002 \\
(0.977)\end{array}$ & & $\begin{array}{l}-0.533 \\
(1.296)\end{array}$ & \\
\hline P_PARTY & $\begin{array}{c}0.474 \\
(0.434)\end{array}$ & & $\begin{array}{c}0.281 \\
(0.619)\end{array}$ & & $\begin{array}{c}0.723 \\
(0.527)\end{array}$ & & $\begin{array}{c}0.219 \\
(0.575)\end{array}$ & \\
\hline GENDER & $\begin{array}{c}0.013 \\
(0.599)\end{array}$ & & $\begin{array}{l}-1.631 \\
(1.124)\end{array}$ & & $\begin{array}{c}0.834 \\
(0.585)\end{array}$ & & $\begin{array}{l}-0.565 \\
(1.111)\end{array}$ & \\
\hline ACADEMIC & $\begin{array}{c}0.902 \\
(0.367)\end{array}$ & ** & $\begin{array}{c}0.569 \\
(1.129)\end{array}$ & & $\begin{array}{c}0.814 \\
(0.908)\end{array}$ & & $\begin{array}{l}-0.631 \\
(1.022)\end{array}$ & \\
\hline GOVT & $\begin{array}{c}1.821 \\
(3.764)\end{array}$ & & $\begin{array}{l}-0.245 \\
(0.163)\end{array}$ & & $\begin{array}{c}0.623 \\
(0.392)\end{array}$ & & $\begin{array}{c}0.216 \\
(0.198)\end{array}$ & \\
\hline INDUSTRY & $\begin{array}{c}0.641 \\
(0.721)\end{array}$ & & $\begin{array}{c}0.931 \\
(1.058)\end{array}$ & & $\begin{array}{c}0.004 \\
(0.888)\end{array}$ & & $\begin{array}{l}-0.591 \\
(0.865)\end{array}$ & \\
\hline ACADEMIC*GOVT & $\begin{array}{c}0.207 \\
(0.697)\end{array}$ & & $\begin{array}{l}-0.008 \\
(0.421)\end{array}$ & & $\begin{array}{c}0.105 \\
(0.876)\end{array}$ & & $\begin{array}{l}-0.052 \\
(0.645)\end{array}$ & \\
\hline ACADEMIC*INDUSTRY & $\begin{array}{c}0.107 \\
(0.897)\end{array}$ & & $\begin{array}{c}0.321 \\
(1.321)\end{array}$ & & $\begin{array}{c}0.205 \\
(1.075)\end{array}$ & & $\begin{array}{c}1.465 \\
(1.245)\end{array}$ & \\
\hline GOVT*INDUSTRY & $\begin{array}{c}0.097 \\
(0.497)\end{array}$ & & $\begin{array}{c}0.121 \\
(0.321)\end{array}$ & & $\begin{array}{c}0.202 \\
(0.856)\end{array}$ & & $\begin{array}{c}0.465 \\
(0.451)\end{array}$ & \\
\hline BOG & $\begin{array}{c}0.841 \\
(0.475)\end{array}$ & $*$ & $\begin{array}{l}-1.545 \\
(0.714)\end{array}$ & ** & $\begin{array}{l}-0.393 \\
(0.533)\end{array}$ & & $\begin{array}{c}1.111 \\
(0.727)\end{array}$ & \\
\hline FOMC_APPT & $\begin{array}{l}-0.007 \\
(0.042)\end{array}$ & & $\begin{array}{l}-0.015 \\
(0.056)\end{array}$ & & $\begin{array}{c}0.007 \\
(0.060)\end{array}$ & & $\begin{array}{c}0.391 \\
(0.166)\end{array}$ & ** \\
\hline FED_JOIN & $\begin{array}{c}0.037 \\
(0.020)\end{array}$ & * & $\begin{array}{c}0.048 \\
(0.027)\end{array}$ & * & $\begin{array}{c}0.018 \\
(0.022)\end{array}$ & & $\begin{array}{l}-0.029 \\
(0.033)\end{array}$ & \\
\hline CHAIR_TIME & $\begin{array}{l}-0.064 \\
(0.027)\end{array}$ & ** & $\begin{array}{l}-0.086 \\
(0.034)\end{array}$ & ** & $\begin{array}{c}0.000 \\
(0.046)\end{array}$ & & $\begin{array}{l}-0.101 \\
(0.031)\end{array}$ & $* * *$ \\
\hline GDP & $\begin{array}{c}0.071 \\
(0.045)\end{array}$ & & $\begin{array}{c}0.021 \\
(0.057)\end{array}$ & & $\begin{array}{c}0.201 \\
(0.078)\end{array}$ & $* *$ & $\begin{array}{c}0.115 \\
(0.118)\end{array}$ & \\
\hline INFLATION & $\begin{array}{c}0.090 \\
(0.076)\end{array}$ & & $\begin{array}{c}0.018 \\
(0.097)\end{array}$ & & $\begin{array}{c}0.212 \\
(0.121)\end{array}$ & $*$ & $\begin{array}{l}-0.008 \\
(0.235)\end{array}$ & \\
\hline YLD_C & $\begin{array}{c}0.065 \\
(0.089)\end{array}$ & & $\begin{array}{c}0.081 \\
(0.112)\end{array}$ & & $\begin{array}{l}-0.027 \\
(0.152)\end{array}$ & & $\begin{array}{c}0.749 \\
(0.312)\end{array}$ & $* *$ \\
\hline Lag(Dependent) & $\begin{array}{l}1.410 \\
(0.196)\end{array}$ & $* * *$ & $\begin{array}{c}1.774 \\
(0.242)\end{array}$ & *** & $\begin{array}{c}1.074 \\
(0.405)\end{array}$ & *** & $\begin{array}{c}4.768 \\
(0.521)\end{array}$ & $* * *$ \\
\hline $\ln \left(\sigma_{v}^{2}\right)$ & $\begin{array}{c}0.554 \\
(0.324)\end{array}$ & & $\begin{array}{c}1.157 \\
(0.365)\end{array}$ & & $\begin{array}{c}1.006 \\
(0.347)\end{array}$ & & $\begin{array}{l}1.358 \\
(0.370)\end{array}$ & \\
\hline$\sigma_{v}$ & $\begin{array}{c}1.319 \\
(0.214)\end{array}$ & & $\begin{array}{c}1.783 \\
(0.326)\end{array}$ & & $\begin{array}{c}1.003 \\
(0.324)\end{array}$ & & $\begin{array}{c}1.972 \\
(0.720)\end{array}$ & \\
\hline$\rho$ & $\begin{array}{c}0.346 \\
(0.073)\end{array}$ & & $\begin{array}{c}0.491 \\
(0.091)\end{array}$ & & $\begin{array}{c}0.234 \\
(0.116)\end{array}$ & & $\begin{array}{c}0.542 \\
(0.181)\end{array}$ & \\
\hline $\begin{array}{l}\text { Likelihood-ratio } \\
\text { Log likelihood }\end{array}$ & $\begin{array}{c}65.69 \\
-598.46\end{array}$ & & $\begin{array}{c}68.79 \\
-397.09\end{array}$ & & $\begin{array}{c}25.96 \\
-241.47\end{array}$ & & $\begin{array}{c}14.58 \\
-88.02\end{array}$ & \\
\hline Wald $\left(\chi_{2,14}\right)$ & 86.15 & & 88.22 & & 33.02 & & 125.17 & \\
\hline Obs. & 3027 & & 3027 & & 3027 & & 3027 & \\
\hline
\end{tabular}

Note: This table presents the estimates for robustness testing of the logit model specified in eq.(3). The dependent variable is a choice variable relating to the decision made by individual FOMC member $k$ at meeting $t$. In column (1) the dependent variable is the choice to dissent (1) or not (0). In column (2) the choice is dissent in favour of tighter monetary policy than decided by the FOMC as whole (1) or not. In column (3) the choice is dissent in favour of easier monetary policy (1) or not (0). Column (4) reflects a choice between dissent on the grounds of language used (1) or not (0). Cluster robust standard errors (Rogers, 1993) are reported in parantheses. Sample period: August 1979 - February 2014. ${ }^{* * *},{ }^{* *},{ }^{*}$ denote significance at the $1 \%, 5 \%$ and $10 \%$ levels respectively. 